\title{
Macroeconomic lockdown and SMEs: the impact of the COVID-19 pandemic in Spain
}

\author{
Luis Pedauga $(\mathbb{D} \cdot$ Francisco Sáez $(\mathbb{D} \cdot$ \\ Blanca L. Delgado-Márquez (i)
}

Accepted: 15 February 2021 / Published online: 5 March 2021

(C) Springer Science+Business Media, LLC, part of Springer Nature 2021

\begin{abstract}
The relative importance of small- and mediumsized enterprises (SMEs) and large firms is a recurrent topic in the small business economics literature. This paper presents a real and financial social accounting matrix (FSAM) capable of distinguishing the direct and indirect effects that are transferred from micro-, small, medium, and large firms to the rest of the economy. We use the hypothetical extraction method (HEM) to explore the sequence of reactions associated with shocks that arise from the COVID-19 lockdown. Using a structural model for the Spanish economy, we identify the role of different firm size categories in the aggregate gross domestic product (GDP). Our results allow us to reconcile the mixed narrative that accompanies the evaluation of the role played by these categories in economic activity by revealing that both SMEs and large firms are important for supporting economic activity. In particular, SMEs help explain $43 \%$ of the income and two-thirds of the unemployment decline caused by the COVID-19 pandemic. Our findings also show the importance of conditioning SME industrial policy to sectoral analysis.
\end{abstract}

\section{Pedauga $(\bowtie)$}

Department of Economics and Statistics, University of León,

Campus de Vegazana, s.n, E-24071 León, Spain

e-mail: luis.pedauga@unileon.es

F. Sáez

Department of Business Economics, University of León, Campus de Vegazana, s.n, E-24071 León, Spain

\section{B. L. Delgado-Márquez}

Department of Business Management, University of Granada, Campus de Cartuja, s/n, E-18071 Granada, Spain
Plain English summary The effects of the macroeconomic lockdown and its transmission to the rest of the economy differ by firm size and across sectors. Using the Spanish context for micro-, small, medium, and large firms, we distinguish the direct and indirect effects caused by the COVID-19 pandemic. The main implications are the following: (1) Research: results emphasize that SMEs and large firms are both important to support economic activity but, in order to account for the relative effects on SMEs, it is crucial to consider the specific sector that receives the disruption. 2) Policy: SMEs are an important focus of business support policies within the EU. According to our estimations, disruptions in SMEs produce larger reductions in demand. These results could support credit policies for SMEs with a strong impact on the aggregate economy due to their greater productive and financial linkages with the domestic economy.

Keywords COVID-19 · SMEs · Macroeconomic lockdown

JEL Classifications D57 E16 E27 $\cdot$ L26

\section{Introduction}

The structural changes experienced by modern economies have stressed the key role of the entrepreneurial economy (Belitski et al. 2019). Research has document- 
ed a relationship between entrepreneurial activity and economic growth (e.g., Acs et al. 2018; Urbano et al. 2019). Academic debate in the macroeconomic sphere on the links of entrepreneurship and unemployment (e.g., Audretsch et al. 2001; Baptista and Thurik 2007; Thurik 2003) and those with economic development (e.g., Audretsch et al. 2015) have been particularly fruitful. Although macroeconomic models have generally been abstracted from entrepreneurship, some econometric exercises have yielded evidence of a connection between entrepreneurial economy and the business cycle (e.g., Koellinger and Roy Thurik 2012). This nexus becomes particularly salient in a rapidly changing context such as that of the COVID-19 pandemic, during which lockdowns have caused a disturbance to economic activity not resembling any other previous demand or supply crisis (Gopinath 2020; Nicola et al. 2020).

While businesses in general, and entrepreneurs in particular, have exhibited high degrees of business resilience (e.g., Bullough and Renko 2013), economic shocks derived from the lockdowns have hit SMEs more severely and produced uneven impacts by sector. SMEs have experienced a reduction in labor supply, human mobility restrictions, self-isolation, large decreases in capacity utilization, and interruptions in supply chains. On the demand side, circular flows of income have been interrupted, by both the cessation of payment wages and lower demand for consumption and investment (Coibion et al. 2020). An array of negative elements such as the deterioration of expectations, fear of contagion, heightened uncertainty, lower incomes, reduction in consumption, and banking credit contraction has provoked dramatic movements in the financial markets (Baker et al. 2020; Zhang et al. 2020).

Similarly, the lower incomes of SMEs have caused severe liquidity shortages and solvency problems. During the economic recession starting in 2008, SMEs had credit restrictions that exacerbated liquidity constraints and led to working capital problems (Bonfim 2009; Lehmann and Neuberger 2001). Economic impacts are not equally distributed across productive sectors or firms during a recession, SMEs are more affected than large firms (Bartik et al. 2020; Narjoko and Hill 2007; Soininen et al. 2012), and sectors such as tourism and transportation are more vulnerable to social distance or confinement. This heterogeneity in firm vulnerability can only be modeled in a framework that explicitly considers the exposure of each sector to multidimensional shocks and their interindustry interactions. The measurement of indirect pandemic impacts has recently been quantified using simulations based on computable general equilibrium (CGE) models. This includes studies measuring the impact of pandemics, taking global (Burns et al. 2006; Lee and McKibbin 2004; Verikios 2017) or country-specific approaches (see, for instance, the analyses by Smith et al. (2011), Thurlow (2011), Keogh-Brown et al. (2010), Dixon et al. (2010), and Kotsopoulos et al. (2019), applied to the UK, Kenya, the USA, Belgium, France, and the Netherlands). To our knowledge, intersectoral models for analyzing business structure have not yet been developed.

This article presents a general equilibrium model for the Spanish economy that breaks down intersectoral relationships in order to distinguish the productive flows from SMEs and large firms. This methodological framework enables the effects of the production restrictions associated with the COVID-19 pandemic to be evaluated. This analysis is particularly relevant for Spain, due to the high sectoral heterogeneity with which these restrictions have impacted economic activity, strongly dependent on the service sector in general, and the spillover effects generated by tourism activity in particular.

This article makes a twofold contribution to the small business economics literature and analysis of the network origins of aggregate fluctuations. First, we propose a more detailed quantification of the effects of workforce shocks on SMEs and a description of how these shocks are transmitted to the aggregate economy. Using the hypothetical extraction method (HEM) according to the proposal by Dietzenbacher et al. (2019), we can determine the relative importance of SMEs in sustaining economic activity and employment throughout the economic cycle and, in particular, during the recession caused by COVID-19.

This study also makes a methodological contribution in developing a quantitative approach to incorporate the industrial sector structure into a general equilibrium model. This is achieved by disaggregating the supply and use tables of the System of National Accounts into categories that correspond to SMEs and large firms. We use a more comprehensive description of the mechanisms of income distribution. Most of the literature on the relationship between sectoral shocks and aggregate fluctuations is based on the real business cycle model by Long Jr. and Plosser (1983). This tradition includes 
seminal works such as those by Jovanovic (1987), Stockman (1988), Horvath (1998, 2000), Dupor (1999), Foerster et al. (2011), and Carvalho and Gabaix (2013). In this approach, the impact of idiosyncratic sectoral shocks on economic activity depends largely on productive interdependencies; however, overall, these studies are bounded to the input-output framework analysis, thus providing only a partial view of the sectorial economic interactions.

Many relationships involve not only the input-output structure but also the financial flows between the different institutional sectors. The absence of these linkages is particularly problematic in analyses of multidimensional economic crises, such as those caused by COVID-19, where firms have been affected simultaneously in terms of labor, goods, and financial markets. We argue that the appropriate model for analyzing these extended issues relies on the financial social accounting matrix (FSAM), which records the transactions of the real activities of economic institutions and presents the complete circular flow of funds in the real economy and the transactions across the financial system (Aray et al. 2017). More specifically, we analyze the effect of supply and demand shocks in disaggregated sectors on the gross domestic product (GDP). This analysis is performed for the first time, according to our knowledge, using an FSAM matrix that distinguishes between SMEs and large firms. In this way, our approach is halfway between approaches reported in the literature of microgranular models and intersectoral network structure (Acemoglu and Azar 2020; Acemoglu et al. 2012, 2016, 2017; Gabaix 2011) and in the literature on social accounting matrices with stochastic exogenous variables and general equilibrium models for the analysis of pandemics (Burns et al. 2006; Dietzenbacher et al. 2019; El Haimar and Santos 2015; Lee and McKibbin 2004; Verikios et al. 2016). We consider the following types of exogenous shocks in this framework: (1) supply shocks that are estimated using the labor inoperability of each firm, grouped according to firm size, (2) demand shocks that are simulated through variations in different components of public spending, and (3) external financial inflows and internal financials shocks. Extracting the empirical shocks from historical data means that the model is capable of reproducing the behavior of the GDP and the second and third stages of its empirical distribution. This paper thus provides added value at this point, as the statistical detail implicit in the structure of the model builds a bridge between aggregate approaches and those based on the analysis of individual productive units (firms). A negative shock on SMEs may thus be analyzed through its direct impact on the aggregated value but also through its indirect impact on salary and operating surplus (profits).

The paper is now structured as follows. In Section 2, we offer a timely review of the literature for pandemic modeling in general and by firm size, in particular, to characterize the current state of knowledge. In Section 3, we present the methodology. Section 4 provides an overview of the dataset, as well as some descriptive statistics. Section 5 reports and explains the results obtained. Finally, Section 6 summarizes the discussion and highlights future research lines.

\section{Literature review on pandemic modeling}

\subsection{Modeling pandemic effects}

Most papers present dynamic models of disease transmission based on susceptible exposed infected recovered (SEIR) models, the pioneering work of which was developed by Kermack and McKendrick (1927). Multiple versions of this framework have shown how pandemics spread and how control measures should be deployed. ${ }^{1}$ Some of these approaches provide epidemiological models that take into account an objective function to evaluate the costs of infection and the associated offsetting interventions (Gersovitz and Hammer 2004). Following this tradition, a growing number of papers emphasize the economic trade-offs and optimal policy analysis and consider different determinants of morbidity. A more recent approach, which this paper follows, explores intersectoral relationships from an input-output model perspective (Dietzenbacher and Lahr 2013; Dietzenbacher and Miller 2015; El Haimar and Santos 2015).

None of these approaches elucidate the relative importance of SMEs and large firms; however, two elements make it possible to overcome this gap. The first is the new availability of statistical data that allows the integration of the productive structure in great detail, within a more aggregate input-output model. The second is the recent development that emphasizes the importance of idiosyncratic shocks (either in sectors or firms) in the explanation of aggregate economic activity.

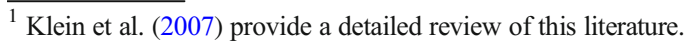


Soininen et al. (2012) point out that idiosyncratic shocks are generally measured through aggregate volatility based on economic and social variables, where it is common to find studies that analyze business bankruptcy using aggregated data over time. Aggregate volatility has been calculated in classical macroeconomics using the central limit theorem, which assumes that all economic sectors are equally represented within an economy and suggests that, although an economy has numerous sectors, the effect of aggregate volatility is minimized at the business level. The traditional argument thus contends that the effects of idiosyncratic shocks at the business level and aggregate fluctuations are based on the law of large numbers.

This suggests that, given the millions of companies that interact in an industrialized economy, idiosyncratic shocks originating in large companies or a group of SMEs would therefore have an aggregate effect that is too insignificant to analyze. The possibility that aggregate instabilities may be due to microeconomic shocks at the firm level, or the level of highly disaggregated sectoral analysis, has long been generally ruled out in macroeconomics due to the diversification argument. This argument was questioned by Gabaix (2011) and Acemoglu et al. (2012), who showed that the central limit theorem should not be applied when there is an extremely wide distribution of business size.

Recent research, such as that by Garicano et al. (2016) and Ebeke and Eklou (2017), demonstrates that when firms size grouping follows a power-law distribution, idiosyncratic shocks are not canceled out and can therefore generate significant aggregate fluctuations. Similarly, Acemoglu et al. (2012) point out that the presence of intersectoral interconnections implies that the effects of microeconomic shocks may not necessarily be confined to their idiosyncratic origin. Rather, microeconomic shocks can spread throughout the economy, affect production in other sectors, and have considerable aggregate effects on the economic performance of other firms. Works such as Gabaix (2011), Acemoglu et al. (2012), and Aray et al. (2017) provide different theoretical frameworks for the analysis of such propagations and can be useful instruments to characterize the transmission mechanisms of idiosyncratic shocks and the scope of aggregate fluctuations as a potential propagation instrument in the economy, under situations of economic vulnerability.
It may be of great interest during the current COVID19 pandemic to have more precise models that incorporate the risk mechanisms of business bankruptcy, credit rationing, and sectoral interrelationships at different levels of firm size (SMEs and large companies) into the analysis. It is therefore necessary to develop robust and information-intensive instruments that allow the behavior of economic agents to be connected at both the level of macroeconomic aggregates and at the firm level to study the impact of aggregate volatility in greater detail and depth in periods of economic turbulence. The instruments developed must have the ability to collect information about the various ways in which economic agents interrelate, making it possible to study how effects in a certain economic sector have an effect on other sectors. Policy recommendations can thus be made to drive strategies at the governmental level aimed at minimizing the effect of both large companies and SMEs ceasing activities.

Although we focus on sector-level linkages instead of firm-specific shocks, our results are compatible with more disaggregate approaches. The transmission of shocks from individual firms to aggregate fluctuations is more intense the higher the concentration of sales (measured through the Herfindahl index) in these firms. Di Giovanni et al. (2014) confirm these results in the French economy, showing that firm-specific shocks in more concentrated industries (e.g., transport, petroleum, and motor vehicles) contribute more to aggregate volatility than firm-specific shocks in less concentrated sectors (e.g., metal products or publishing). Di Giovanni et al. (2014) explain the contribution made by firm shocks to aggregate fluctuations by firm-to-firm covariance terms, which they interpret as evidence of linkages. In our model, by contrast, these interconnections appear specifically at the sectoral firm size level and cost structure.

\subsection{SMEs vs. large firms}

Although one of the main components of development strategy for many governments and donors is facilitating access to funding for SMEs, the extent to which SME finance and credit facilities contribute to economic development and poverty reduction remains unclear (Kersten et al. 2017). This lack of clarity means that many financial subsidy programs have uncertain outputs. Moreover, these industrial policies could be based on preconceptions about the relative importance of 
small versus large firms. For example, a widespread view suggests that large companies are an important engine for growth, exports, and competitiveness, but despite this, SMEs are great creators of employment and entrepreneurial activity.

There is a mixed narrative regarding the importance of different firm sizes. On the one hand, large firms are prominent in modern economies, and this has important implications. It seems natural that idiosyncratic shocks for large firms can lead to nontrivial aggregate shocks. Microeconomic shocks in the top 100 firms in the USA account for a third of aggregate US GDP fluctuations (Gabaix 2011). Large firms also experience important aggregate impacts through spillover effects, supply chain linkages, and the ability to be involved in big contracts, which are less easily accessible to SMEs (Ebeke and Eklou 2017). The importance of sectoral trade exports, which are concentrated among only a few very large firms, is also remarkable. Freund and Pierola (2015) showed that export superstars account for over $80 \%$ of the variation in exports across sectors, while the top five firms make up $30 \%$ of total non-oil exports in 32 countries. They also show that, in many cases, the total revealed comparative advantage could be created by a single firm.

On the other hand, a brief statistical compilation on the relative importance of SMEs may be sufficient to comprehend the interest of policy-makers in designing policies to strengthen and protect them. In industrialized countries, SMEs represent more than $90 \%$ of all companies, employ approximately two-thirds of the labor force, and contribute about $50 \%$ of the added value of nonagricultural production (Baas and Schrooten 2006). Furthermore, it is generally accepted that SMEs play a fundamental role in promoting economic growth and job creation and in reducing poverty (Beck et al. 2005; Garicano et al. 2016; Paul et al. 2007; Wagenvoort 2003). Ayyagari et al. (2007) show how the share of formal SMEs in manufacturing increases as countries grow richer, while the informal sector loses importance. In the same way, they found that several dimensions of the business environment are associated with a larger SME sector.

When weighing the relative benefits of SMEs, various dimensions of analysis appear. This multiplicity of elements, such as economic growth, level of employment, or technical progress, makes evident policy dilemmas that highlight the multi-objective nature of the industrial policy. For example,
Ayyagari et al. (2011) show that while small firms employ a large share of workers and create most jobs in developing economies, their contribution to productivity growth is not as great as that of large firms. Small and large companies, however, are part of an inseparable productive network. The general equilibrium approach suggests that, rather than being analyzed as separated objects, interdependencies between SMEs and large companies should be analyzed in a unified framework. This article addresses how sectoral shocks associated with confinement restrictions could have a different impact on GDP. Although property rights protection, entry costs, and credit information could affect the employment share of SMEs according to Ayyagari et al. (2011), our analysis is more focused on the short term. It thus emphasizes the interrelationships that arise at the level of the goods market, the labor and financial markets, and the secondary distribution of income. In this sense, we accentuate elements of SMEs related to sectoral complementarity and productive spillovers in the business cycle.

\section{Research methodology}

\subsection{FSAM framework}

We use an input-output model that incorporates integrated economic accounts to define the FSAM for the Spanish economy, all within the accounting framework of the National System of Accounts. The real sector economy and the financial sectors are linked following the proposal by Aray et al. (2017). The FSAM captures circular interdependence characteristics that the inputoutput model does not. These include (a) production activities, (b) factorial income distribution, (c) income distribution between different institutions, and (d) financial flows and investment-saving results (Aray et al. 2017; Defourny and Thorbecke 1984).

From a policy design perspective, this structural framework takes into account not only the response of the economy to lockdown shock but also the relative importance of each of the firm size categories. This provides a complete picture of how the product is generated and how the income of the economy is distributed between the different firm size categories. The general equilibrium approach allows us to address two research questions: How 
much do SMEs and large firms depend on each other? What is the firm size driving effect of the growth? We rely on the HEM according to the proposal by Dietzenbacher et al. (2019) to answer those questions. This technique allows us to examine the effect of this extraction on other sectors in the economy (totally or partially).

The model includes 63 activities that have been disaggregated by firm size (micro, small, medium, and large), which implies an expansion to 248 activities. The model also has all the financial details associated with the instruments and institutional sectors, which allows analysis of the interconnections between the real and financial sectors.

The assumption of price rigidity or perfect complementarity between productive inputs should not be problematic in our framework for two reasons. The empirical estimates of the degrees of substitution between inputs have been assessed as lower values than the elasticity of unit substitution implied by the Cobb-Douglas production function in previous research. Atalay (2017) thus estimates that the production elasticities of substitution are, on the whole, small. As a result, sectoral shocks are more important than previously thought. Similarly, Pasten et al. (2020) argue that price rigidity contributes to the importance of micro-shocks driving aggregate volatility. There is also no clear effect of the COVID-19 pandemic on price level in the short term. Farhi and Baqaee (2020) argue that demand and supply shocks are both necessary to make sense of the data: "Both shocks together result in a large reduction in GDP and muted reaction in inflation" (p. 57).

\subsection{Fixed-priced multiplier model}

An FSAM yields a comprehensive and economywide System of National Accounts recording data about all transactions between economic agents in a specific economy for a specific period of time (Miller and Blair 2009). It includes interindustry linkages through transactions typically found in the input-output model but extends it by including the complete circular flow of income, capital, and financial accounts in the economy. It can be represented by a square matrix $T$ of monetary flows, designed to provide a record of transactions using a single-entry form of bookkeeping (Pyatt 1988), as follows:

$\mathbf{T}=\left[t_{i j}\right]=\left[\begin{array}{cccccc}0 & \mathbf{I C} & 0 & \mathbf{C} & \mathbf{K} & 0 \\ \mathbf{O} & 0 & 0 & 0 & 0 & 0 \\ 0 & \mathbf{V A} & 0 & 0 & 0 & 0 \\ 0 & 0 & \mathbf{V A}^{*} & \mathbf{P I} & 0 & 0 \\ 0 & 0 & 0 & \mathbf{S} & \mathbf{K T} & \mathbf{F L} \\ 0 & 0 & 0 & 0 & \mathbf{F A} & 0\end{array}\right]$

where $i$ is the number of row transactions, $j$ is the number of column transactions, and the total number of transactions, called accounts, constitutes the dimension of the square matrix. By convention, rows represent incomes (resources), and columns describe expenditures (uses). Therefore, $t_{i j}$ shows the transaction value corresponding to the income obtained by account $i$ as a result of the expenditure originating in account $j$ during an accounting period. Each account constitutes a set of submatrices defined by the symmetric dimension of commodities and industries $(m)$, value-added categories $(k)$, institutional sector $(p)$, and financial instruments $(q)$. The set of a system of linear equations included in $\mathbf{T}$ constitutes a sequence of accounts that begins with the sphere of the real economy by recording the output in the production matrix $\left(\mathbf{O}_{m \times m}\right)$, the input of the intermediate consumption matrix $\left(\mathbf{I C}_{m \times m}\right)$, and leaving the value-added $\left(\mathbf{V} \mathbf{A}_{k \times m}\right)$ as the matrix balancing item. The generation of income and distribution area, represented by matrices $\mathbf{V A}_{p \times k}^{*}, \mathbf{P I}_{p \times p}, \mathbf{C}_{p \times p}^{*}$, and $\mathbf{S}_{p \times p}$, describes how production factors (such as labor and capital) generate income and transfer it to their institutional sector $\left(\mathbf{V A}_{p \times k}^{*}\right)$ and how this is augmented by the dividends and interests received from owning financial assets and natural resources, which are in turn represented by the property income matrix $\left(\mathbf{P I}_{p \times p}\right)$. Each institutional sector also allocates its disposable income between final consumption expenditures $\left(\mathbf{C}_{p \times p}^{*}\right)$ and savings $\left(\mathbf{S}_{p \times p}\right)$. Finally, the financial interconnectedness with the real sector of the economy is recorded in the accumulation account by institutional sectors, savings, net capital transfer $\left(\mathbf{K T}_{p \times p}\right)$, and financial liability flows $\left(\mathbf{F L}_{p \times q}\right)$, which are used to acquire nonfinancial $\left(\mathbf{K}_{p \times p}^{*}\right)$ and financial asset flows $\left(\mathbf{F} \mathbf{A}_{q \times p}\right)$.

The standard input-output model distinguishes commodities $i=1, \ldots, m$ and activities $j=1, \ldots, m$. At the most disaggregated level (microdata), an activity constitutes a representative firm. Thus, a firm $j$ uses inputs 
(both factor services and commodities) to make products (commodities). For national accounting, it is customary to list the inputs in the $j$-th column of the use matrix $\mathbf{I} \mathbf{C}_{m \times m}=i c_{i j}$ but the outputs in the $i$-th row of the make matrix $\mathbf{O}_{m \times m}=o_{i j}$. In this sense, to understand the role played by firms according to their size in depth, this research proposes to break down the detail of the inputoutput sectoral accounts as follows:

$\left[\begin{array}{cc}0 & \mathbf{I C} \\ \mathbf{0} & 0\end{array}\right]=\left[\begin{array}{ccccc}0 & \overbrace{i c_{i j}^{m i}} & i c_{i j}^{S} & i c_{i j}^{M} & \overbrace{i c_{i j}^{L}}^{\text {LME }} \\ o_{i j}^{m i} & 0 & 0 & 0 & 0 \\ o_{i j}^{S} & 0 & 0 & 0 & 0 \\ o_{i j}^{M} & 0 & 0 & 0 & 0 \\ o_{i j}^{L} & 0 & 0 & 0 & 0\end{array}\right]$

For analytical purposes, when implementing the International Standard Industrial Classification (ISIC) at its lower levels of detail, as proposed here, the economic interactions taking place between the different activities and heterogeneous firms can be observed according to $n$ size categories, micro $(m i)$, small $(S)$, medium $(M)$, and large $(L)$ firms, allowing an understanding of the interindustry linkages in production in an economy (United Nations, Commission of the European Communities, International Monetary Fund, Organization for Economic Co-operation, and Development and World Bank 2008).

Because an FSAM inherits the features of a modular analytical structure, the formal framework for analyzing the effects of diverse economic shocks through the information contained in matrix $\mathbf{T}$ is a multiplier analysis, as proposed by Emini and Fofack (2004). This framework allows the impact of real shocks to be simulated, using a multiplier model that treats the circular flow of income endogenously by configuring a fixedprice multiplier model typically specified by the set of equations below:

$\mathbf{y}=\mathbf{A y}+\mathbf{x}=(\mathbf{I}-\mathbf{A})^{-1} \mathbf{x}=\mathbf{M} \mathbf{x}$

where $\mathbf{y}$ represents a vector of endogenous variables (accounts) and $\mathbf{x}$ is a vector of exogenous variables (accounts). If $\mathbf{A} \equiv \mathbf{T}(\widehat{\mathbf{y}})^{-\mathbf{1}}$ defines the matrix of average propensities of expenditures for endogenous accounts (assumed to be fixed) and $\mathbf{I}$ is the identity matrix, then matrix $\mathbf{M}$ (also fixed) contains the aggregate accounting multipliers that quantify the increment of the endogenous account, $i$, caused by the increase in one monetary unit of the exogenous account.

The interpretation of the values in $\mathbf{M}$ is straightforward. The impact of any given injection into the exogenous accounts is transmitted through the interdependent system of equations expressed in (3) and expanded by (2) among the endogenous accounts. The interwoven nature of the system implies that the impact multiplier captures the overall effects (direct, indirect, and induced) of a unitary and exogenous shock on output, income, and financial accounts (Miller and Blair 2009).

\subsection{Hypothetigal extraction method}

The relevance of a sector or a group of firms within an economy has been a matter of interest for a long time (Dietzenbacher et al. 2019). The HEM is a widely accepted approach for describing intersectoral linkages and the importance of sectors (Dietzenbacher et al. 2019). The analysis of intersectoral linkages based on the HEM has therefore become increasingly popular (Miller and Lahr 2001) and widely applied to numerous studies examining, for example, the economy-wide influence of sectors (Perobelli et al. 2015), regional interdependence (Guerra and Sancho 2010), the role of multinational enterprises (Cadestin et al. 2019), and the analysis of specific sectors, such as the construction sector (Song et al. 2006), or the real estate sector (Song and Liu 2007). ${ }^{2}$ However, little attention has been paid to the intersectoral connectedness of enterprises according to firm size. The lack of studies is noticeable, although it is well known that SMEs are the main employment creators and also the main contributors to GDP in most economies (OECD 2019).

The main idea behind the HEM is the hypothetical situation in which a particular sector (or group of sectors: micro-, small, medium, or large firms) of dimension $m_{(-)}$is no longer operational, and it examines the effect of this extraction on the remaining $m_{(+)}\left(m_{(+)}+\right.$ $m_{(-)}=m$ ) sectors in the economy (Miller 1966; Paelinck et al. 1965; Strassert 1968). Without loss of generality, the method assumes that the $m$ sector embedded in matrix $\mathbf{A}$ as expressed in equation (3) can be partitioned into two types of group: a group $m_{(-)}$containing a group of sectors to be extracted from the economy and another

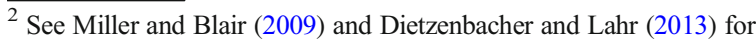
insight and extensions.
} 
group $m_{(+)}$containing the sectors remaining in the economy. ${ }^{3}$ As per Dietzenbacher and Lahr (2013), the fixedprice multiplier model would then be expressed as follows:

$$
\left[\begin{array}{l}
\mathbf{y}_{(-)} \\
\mathbf{y}_{(+)}
\end{array}\right]=\left[\begin{array}{ll}
\mathbf{A}_{11} & \mathbf{A}_{12} \\
\mathbf{A}_{\mathbf{2 1}} & \mathbf{A}_{\mathbf{2 2}}
\end{array}\right] \times\left[\begin{array}{l}
\mathbf{y}_{(-)} \\
\mathbf{y}_{(+)}
\end{array}\right]+\left[\begin{array}{l}
\mathbf{x}_{(-)} \\
\mathbf{x}_{(+)}
\end{array}\right]
$$

where $\mathbf{y}_{(-)}$and $\mathbf{y}_{(+)}$are vectors of size $m_{(-)} \times 1$ and $m_{(+}$ , $\times 1$, respectively, denoting the total output of each sector, and similarly the vectors $\mathbf{x}_{(-)}$and $\mathbf{x}_{(+)}$, standing for the exogenous final demand vectors of similar size as before. Meanwhile, the submatrices $\mathbf{A}_{\mathbf{1 1}}$ and $\mathbf{A}_{\mathbf{2 2}}$ are squares of size $m_{(-)} \times m_{(-)}$and $m_{(+)} \times m_{(+)}$, respectively, and the remaining submatrices $\mathbf{A}_{12}$ and $\mathbf{A}_{21}$ are of size $m_{(-)} \times m_{(+)}$and $m_{(+)} \times m_{(-)}$, respectively.

Linkage measures based on the HEM usually try to quantify how much an economy's total output would decrease if a sector was extracted from the domestic economy. This implies that extracting $m_{(-)}$sector gives $\mathbf{A}_{\mathbf{1 2}}=\mathbf{A}_{\mathbf{2 1}}=\mathbf{0}$, and the final demand for products from this sector, $m_{(-)}=\mathbf{0}$, yields a new reduced form of expression (4) such that:

$\overline{\mathbf{y}}=\overline{\mathbf{A}}_{\boldsymbol{m}_{(-)}} \overline{\mathbf{y}}+\overline{\mathbf{x}}=\left[\begin{array}{c}\overline{\mathbf{y}}_{(-)} \\ \overline{\mathbf{y}}_{(+)}\end{array}\right]=\left[\begin{array}{cc}\mathbf{A}_{\mathbf{1 1}} & \mathbf{0} \\ \mathbf{0} & \mathbf{A}_{\mathbf{2 2}}\end{array}\right] \times\left[\begin{array}{c}\overline{\mathbf{y}}_{(-)} \\ \overline{\mathbf{y}}_{(+)}\end{array}\right]+\left[\begin{array}{c}\mathbf{0} \\ \mathbf{x}_{(+)}\end{array}\right]$

where $\overline{\mathbf{A}}_{\boldsymbol{m}_{(-)}}$is a new input matrix with all of the interindustry linkages to sector $\boldsymbol{m}_{(-)}$nullified. The difference between expressions (4) and (5) solves the sectoral output losses when sector $\boldsymbol{m}_{(-)}$is no longer present in the economic system. Using $\Delta \overline{\mathbf{y}}_{\boldsymbol{m}_{(-)}}$to denote the difference before and after the extraction of sector $\boldsymbol{m}_{(-)}$ (called the total linkage), we get:

$\Delta \overline{\mathbf{y}}_{\boldsymbol{m}_{(-)}}=\mathbf{y}-\overline{\mathbf{y}}=\left((\mathbf{I}-\mathbf{A})^{-1}-\left(\mathbf{I}-\overline{\mathbf{A}}_{\boldsymbol{m}_{(-)}}\right)^{-\mathbf{1}}\right) \overline{\mathbf{x}}$

The HEM approach uses vector differences $\Delta \overline{\mathbf{y}}_{\boldsymbol{m}_{(-)}}$ to address the so-called key sector identification problem in an interconnected economy - the sectors with the highest potential for spreading growth impulses throughout the economy (Temurshoev 2010).

The literature on HEM has focused mainly on quantifying the decrease in an economy's total output (or other indicators) when the "entire" industry in an

\footnotetext{
${ }^{3}$ The results can be then referred to a single sector by assuming $m_{(-)}=$ 1 .
}

economy ceases to exist after some shock (for insight and extensions, see Dietzenbacher and Lahr 2013; Miller and Blair 2009). Dietzenbacher and Lahr (2013) expanded the HEM to explore situations in which a sector is only partially extracted. They specifically consider assessing the effects of a partial extraction when detailed information about firms was available (microdata). Their proposal is useful because it analyzes the repercussions for the economy if, for example, a group of firms (mimicking a homogenous establishment) within a sector (i.e., an aggregate industry) ceased to exist.

In line with Dietzenbacher and Lahr (2013), this research applies a partial HEM to explore the role played by SMEs and large firms at a national level and the quantitative interdependence between these firms and the remaining sectors of the economy. In addition, and under a fixed-price model assumption, we are now in a position to address the key sector identification problem at a microlevel by extracting a group of firms (SMEs or large) from the entire economic system to generate the largest possible reduction in total linkages i $\Delta \overline{\mathbf{y}}_{-\boldsymbol{m}_{1}}$, where $\mathbf{i}$ is the summation vector of linkages.

\section{Dataset and descriptive analysis}

The Spanish National Bureau of Statistics (INE by its Spanish acronym) presented the definitive results of the "Project for the integration of structural business surveys" (Instituto Nacional de Estadística (INE) 2019). This project involved the detailed study of three of the most important sectors in the Spanish economy (industry, commerce, and service) which is based on 2015 and with information available until 2017. This study is based on a harmonized sample design and is homogenized with the System of National Accounts (United Nations, Commission of the European Communities, International Monetary Fund, Organization for Economic Co-operation, and Development and World Bank 2008), so its results provide valuable information on the structural and economic characteristics of firms, such as their size (micro, small, medium, and large), economic data (income and expenses), and the structure of employment and investment (see Table 1 for a distribution of firms by size).

In this sense, we integrate the statistics produced by INE of the System of National Accounts (SNA) with the 
statistics elaborated by the Bank of Spain (BDE, in its Spanish acronym) for the financial system, and incorporate them into an instrument that allows the interrelationships between the real and the financial sectors of the economy to be identified. The results of the Enterprise Structure Surveys (Instituto Nacional de Estadística (INE) 2019) can be integrated into the general equilibrium model using the results presented by Aray et al. (2017). In doing so, our research enables the construction of an FSAM with detail broken down by firm size (micro, small, medium, and large) which can be used as modeling base guidelines consistent with the SNA (see Table 7 for a detailed overview of firm size classification).

The lockdown assessment comes from the estimate made by the INE based on the information contained in the central directory of firms. To prepare this assessment, each activity has been identified according to the Annex of Royal Decree-Law 10/2020 of March 29 (see Table 8), in which so-called "essential activities" are identified. This step is a purely statistical criterion to provide information that gives an idea of the weight of these essential activities in the economy as a whole, distributed by various territorial breakdowns in terms of firms and employment.

It is convenient to use the income and production approach to analyze the relative importance of SMEs under COVID-19 supply-demand shock. Table 2 shows that SME production is slightly lower than that of large firms (48.3 vs. 51.7\%). The higher income of large firms also translates into a higher share of employee compensation and gross operation surplus relative to that of SMEs. The annual labor productivity in large firms, calculated as added value per person employed based on the FSAM of 2016 (see Tables 1 and 2), results in 65,700 euros, which implies a figure $60 \%$ higher than the productivity observed in SMEs (41,000 euros). Similar results can be found for the European average, where labor productivity between 2008 and 2016 is stationary around 62\% (European Commission 2019). ${ }^{4}$ Similarly, Table 2 shows that SMEs exhibit a greater dependence on the internal economy if we consider their higher level of intermediate consumption $(51.2 \%$ of gross product). Although those weights do not demonstrate significant differences between SMEs and large

\footnotetext{
${ }^{4}$ According to the European Commission (2019), SMEs' productivity in Spain has not yet recovered from the 2008 crisis, unlike large firms, which have already surpassed their pre-crisis level of productivity.
}

firms, the results displayed in the next section suggest how the sectoral approach completely changes the perspective when considering the interlinkages measured through the HEM.

\section{Results}

We present the impacts on production, valued added, and employment in two scenarios in order to analyze the results of the model. In the first simulation, we consider a total extraction of SMEs and large firms (we generically label this simulation as HEM in Table 3). In the second simulation, we consider only that part of the productive extraction that can be justified by the lockdown measures contained in the Royal Decree of April (we generically label this simulation "the lockdown effect" in Tables 4 and 5). To understand the breakdown, Tables 3 and 4 distinguish between direct effects (associated with cross-sectoral relationships), indirect effects (related to the income primary distribution mechanism), and induced effects (associated with the secondary distribution of income).

We highlight the effects of the income distribution, in particular the importance of large firms in the determination of total labor income in aggregate demand. For example, Table 3 shows that the removal of all large firms would result in a $67.93 \%$ destruction of economic activity (although their direct involvement in GDP, as shown in Table 2, is $51.7 \%$ ). Moreover, a hypothetical extraction of all SMEs would imply the loss of $61.57 \%$ value-added (although their direct share of the total aggregate value is $48.3 \%$ ).

Although SMEs and large firms have approximately the same weight in their aggregate contribution, the compensation of employee reduction associated with the elimination of large firms in the economic system (both indirect and induced) ends up having a greater aggregate effect on GDP; however, this greater impact on the aggregate wage mass does not imply as high an impact on the level of employment. Table 4 presents the impact on total employment in the economy associated with the lockdown measures. SMEs account for $62 \%$ of the impact on employment, mainly explained by variation at the level of microenterprises.

Figure 1 shows the impact on each sector when extracting SMEs and large firms. A detailed analysis of the sectors suggests that the "disappearance" of the former has a slightly higher impact on the added value. 
Table 1 Distribution (number and employees) of firms by size in social accounting matrices in Spain (2016)

\begin{tabular}{|c|c|c|c|c|}
\hline \multirow[t]{2}{*}{ Employment size classification } & \multicolumn{2}{|l|}{ Firms } & \multicolumn{2}{|l|}{ Employees } \\
\hline & Total number & Share in $\%$ & Total number & Share in $\%$ \\
\hline SMEs $(<250$ persons engaged $)$ & $3,170,513$ & 88.96 & $11,748,709$ & 59.89 \\
\hline Microenterprises $(<10$ persons engaged $)$ & $3,007,672$ & 84.39 & $7,077,586$ & 36.08 \\
\hline Small enterprises (between 10 and 49 persons engaged) & 144,491 & 4.05 & $2,978,214$ & 15.18 \\
\hline Medium enterprises (between 50 and 249 persons engaged) & 18,349 & 0.51 & $1,692,909$ & 8.63 \\
\hline Large enterprises (> 249 persons engaged $)$ & 393,320 & 11.04 & $7,866,991$ & 40.11 \\
\hline Total & $3,563,833$ & 100 & $19,615,700$ & 100 \\
\hline
\end{tabular}

Source: Own calculations based on the Annual Spanish National Accounts (2019 Benchmark Revision) and the results of the Project of Integration of Structural Business Statistics (INE, 2019)

This can be seen because in SMEs (52.17\%), the impact on demand by products is greater than the impact obtained in large firms (47.83\%). This effect is intensified when extracting large enterprises and SMEs derived from the lockdown caused by COVID-19 (see Fig. 2). The impact on demand by products in SMEs (73.91\%) under the lockdown scenario is greater than the impact in large firms (26.09\%).

Two things must be taken into account when analyzing the lockdown effect on aggregate demand. First, SMEs have a higher intermediate consumption component (53\% for the SMEs vs. $47 \%$ for large firms). Second, the Royal Decree of March 29 finally affected those sectors with higher relative intermediate consumption to a greater extent. This means that SMEs are more impacted by aggregate demand than large firms. This is particularly true for activities in the professional and business services, real estate, and some manufacturing sectors (see Table 5 and Fig. 2). The sensitivity of sectoral demand to sectoral hypothetical extraction, according to the announced confinement policy, may thus also offer insights into the relative sector vulnerability based on the interrelationships, both at the level of industrial interrelationships and in the area of the income distribution.

The exercise also highlights the complex nature of the type of shock involved in the closure of economic activities. On the one hand, cessation of activities

Table 2 Annual Spanish national accounts: main aggregates by firm size from social accounting matrices (2016) (million euros)

\begin{tabular}{|c|c|c|c|c|c|c|c|c|}
\hline & \multirow{2}{*}{$\begin{array}{l}\text { Code } \\
\text { SNA }\end{array}$} & \multirow[t]{2}{*}{ Concept } & \multicolumn{3}{|l|}{ SMEs } & \multirow[t]{2}{*}{ Subtotal } & \multirow[t]{2}{*}{ Large } & \multirow[t]{2}{*}{ Total } \\
\hline & & & Micro & Small & Medium & & & \\
\hline \multirow[t]{6}{*}{ Income approach } & \multirow[t]{2}{*}{ D.1 } & \multirow[t]{2}{*}{ Compensation of employees } & 85,411 & 81,045 & 61,873 & 228,329 & 275,395 & 503,724 \\
\hline & & & $16.96 \%$ & $16.09 \%$ & $12.28 \%$ & $45.33 \%$ & $54.67 \%$ & $100 \%$ \\
\hline & \multirow[t]{2}{*}{ B. $2 b$} & \multirow{2}{*}{$\begin{array}{l}\text { Operation surplus, gross / Mixed income, } \\
\text { gross }\end{array}$} & 101,257 & 92,626 & 60,239 & 254,121 & 241,698 & 495,819 \\
\hline & & & $20.42 \%$ & $18.68 \%$ & $12.15 \%$ & $51.25 \%$ & $48.75 \%$ & $100 \%$ \\
\hline & \multirow[t]{2}{*}{ B.1b } & \multirow[t]{2}{*}{ Gross value added at basic prices } & 186,668 & 173,671 & 122,112 & 482,450 & 517,093 & 999,543 \\
\hline & & & $18.68 \%$ & $17.38 \%$ & $12.22 \%$ & $48.27 \%$ & $51.73 \%$ & $100 \%$ \\
\hline \multirow{6}{*}{$\begin{array}{l}\text { Production } \\
\quad \text { approach }\end{array}$} & \multirow[t]{2}{*}{ B. $1 \mathrm{~b}$} & \multirow[t]{2}{*}{ Gross value added at basic prices } & 186,668 & 173,671 & 122,112 & 482,450 & 517,093 & 999,543 \\
\hline & & & $55.64 \%$ & $48.41 \%$ & $41.60 \%$ & $48.84 \%$ & $53.51 \%$ & $51.15 \%$ \\
\hline & \multirow[t]{2}{*}{ P. 2} & \multirow[t]{2}{*}{ Intermediate consumption } & 148,815 & 185,086 & 171,449 & 505,351 & 449,274 & 954,625 \\
\hline & & & $44.36 \%$ & $51.59 \%$ & $58.40 \%$ & $51.16 \%$ & $46.49 \%$ & $48.85 \%$ \\
\hline & \multirow[t]{2}{*}{ P.1 } & \multirow[t]{2}{*}{ Gross product at basic prices } & 335,483 & 358,757 & 293,561 & 987,801 & 966,367 & $1,954,168$ \\
\hline & & & $100 \%$ & $100 \%$ & $100 \%$ & $100 \%$ & $100 \%$ & $100 \%$ \\
\hline
\end{tabular}

Source: Own calculations based on the Annual Spanish National Accounts (2019 Benchmark Revision) and the results of the Project of Integration of Structural Business Statistics (INE, 2019) 
Table 3 Hypothetical extraction impact: total extraction of SMEs and large firms (\% loss in main aggregates)

\begin{tabular}{|c|c|c|c|c|c|}
\hline Code SNA & Concept & Direct & Indirect & Induced & Total effects \\
\hline \multicolumn{6}{|l|}{ SMEs } \\
\hline D.1 & Compensation of employees & 38.50 & 22.14 & 2.43 & 63.07 \\
\hline B. $2 b$ & Operation surplus, gross/mixed income, gross & 29.99 & 34.72 & 9.53 & 74.25 \\
\hline B. $1 \mathrm{~b}$ & Gross value added at basic prices & 23.76 & 17.98 & 19.83 & 61.57 \\
\hline \multicolumn{6}{|c|}{ Large enterprises } \\
\hline D.1 & Compensation of employees & 44.50 & 25.02 & 7.24 & 76.76 \\
\hline B. $2 b$ & Operation surplus, gross/mixed income, gross & 40.27 & 25.66 & 8.68 & 74.61 \\
\hline B. $1 \mathrm{~b}$ & Gross value-added at basic prices & 25.82 & 15.49 & 26.62 & 67.93 \\
\hline
\end{tabular}

Source: Own calculation

implies, by definition, the destruction of value added from the perspective of the production approach but, simultaneously, produces a reduction in gross aggregate demand (Table 6), the latter due to the reduction in income and the consequent impact on aggregate consumption (final and intermediate) and investment levels. In the absence of radical changes in consumer prices, the new balance occurs through variation in inventories, net imports, and rationing.

\section{Discussion}

\subsection{Conclusions}

The relative effect of SMEs and large firms on economic growth and welfare remains an open subject of research and debate (Kersten et al. 2017). Firms are tightly interconnected through a network of mechanisms that are involved not only with intersectoral relationships but

Table 4 Lockdown effect on employment partial extraction of SMEs and large firms (\% loss employees)

\begin{tabular}{lcccc}
\hline Firm size category & Direct & Indirect & Induced & Total effects \\
\hline SMEs & $\mathbf{2 . 4 9}$ & $\mathbf{4 . 4 6}$ & $\mathbf{2 . 7 1}$ & $\mathbf{9 . 6 6}$ \\
Microenterprises & 1.34 & 2.94 & 1.72 & 5.99 \\
Small enterprises & 0.70 & 0.98 & 0.64 & 2.32 \\
Medium enterprises & 0.46 & 0.54 & 0.35 & 1.35 \\
Large enterprises & $\mathbf{2 . 2 8}$ & $\mathbf{2 . 6 0}$ & $\mathbf{1 . 0 4}$ & $\mathbf{5 . 9 1}$ \\
Total impact & $\mathbf{4 . 7 7}$ & $\mathbf{7 . 0 6}$ & $\mathbf{3 . 7 5}$ & $\mathbf{1 5 . 5 8}$ \\
\hline
\end{tabular}

The partial extraction is based on the share of essential activities allowed to provided services during the lockdown, according to RD 10/2020 of March 29

Source: Own calculation also with income distribution mechanisms. This productive complexity means that industrial policies that affect large companies also end up impacting small ones and vice versa. This article analyzes the effects of sectoral idiosyncratic shocks on GDP at the level of the different sectors so as to provide a complete assessment of these interdependencies. We rely on an FSAM with 63 activities that have been disaggregated by firm size: micro, small, medium, and large.

Our approach makes two main contributions to the knowledge frontier in the existing academic frameworks of small business economics and the granular origins of aggregate fluctuations. First, we quantify the economic activity impact originating through different firm size categories in the context of the COVID-19 pandemic. In doing so, we demonstrate the feasibility of maintaining a consistent macroeconomic accounting framework which connects shocks in SMEs and large firms and their aggregated levels effects. Our approach also makes a contribution in the mainstream academic analyses of the micro-foundations of macroeconomic fluctuations (i.e., standard business cycle theory, with micro-features, and the granular origins of aggregate fluctuations).

Our results, from using HEM, reveal that SMEs and large firms are both important to support economic activity. These results allow us to reconcile the mixed narrative that accompanies the evaluation of the role played by these categories in economic activity. In order to account for the relative effects on SMEs, however, it is important to consider the specific sector that receives the disruption. The decline in SMEs due to the effect of the COVID-19 pandemic accounted for some $43 \%$ of the total decline in activity observed up to July 2020. SMEs were also responsible for two-thirds of the fall in employment. Thus, while the maintenance of economic 
Table 5 Lockdown effect by commodities partial extraction of SMEs and large firms (\% loss in gross demand)

\begin{tabular}{|c|c|c|c|}
\hline \multirow[t]{3}{*}{ Code SNA } & \multirow[t]{3}{*}{ Products } & \multicolumn{2}{|c|}{ Lockdown effect } \\
\hline & & \multicolumn{2}{|l|}{ Loss $\%$} \\
\hline & & SMEs & Large \\
\hline P01 & Products of agriculture, hunting and related services & 28.5 & 26.1 \\
\hline $\mathrm{P} 02$ & Products of forestry, logging and related services & 38.4 & 32.4 \\
\hline P03 & Fish and other fishing products; aquaculture products & 32.5 & 34.9 \\
\hline $\mathrm{P} 04$ & Mining and quarrying & 40.2 & 37.2 \\
\hline P05 & Food products; beverages; tobacco products & 33.8 & 29.9 \\
\hline P06 & Textiles; wearing apparel; leather and related products & 28.8 & 26.3 \\
\hline $\mathrm{P} 07$ & Wood and of products of wood and cork, except furniture & 61.4 & 37.5 \\
\hline P08 & Paper and paper products & 38.2 & 33.4 \\
\hline P09 & Printing and recording services & 58.5 & 45.7 \\
\hline $\mathrm{P} 10$ & Coke and refined petroleum products & 33.0 & 29.5 \\
\hline P11 & Chemicals and chemical products & 30.8 & 30.0 \\
\hline $\mathrm{P} 12$ & Basic pharmaceutical products and pharmaceutical preparations & 20.4 & 22.2 \\
\hline P13 & Rubber and plastics products & 39.9 & 36.7 \\
\hline P14 & Other non-metallic mineral products & 51.3 & 36.4 \\
\hline $\mathrm{P} 15$ & Basic metals & 49.2 & 44.8 \\
\hline P16 & Fabricated metal products, except machinery and equipment & 47.6 & 45.7 \\
\hline P17 & Computer, electronic and optical products & 36.5 & 35.6 \\
\hline P18 & Electrical equipment & 40.6 & 35.2 \\
\hline P19 & Machinery and equipment $\mathrm{n}$ & 34.5 & 28.7 \\
\hline P20 & Motor vehicles, trailers and semi-trailers & 23.0 & 29.5 \\
\hline $\mathrm{P} 21$ & Other transport equipment & 27.8 & 34.0 \\
\hline $\mathrm{P} 22$ & Furniture; other manufactured goods & 34.3 & 41.5 \\
\hline $\mathrm{P} 23$ & Repair and installation services of machinery and equipment & 47.9 & 42.3 \\
\hline $\mathrm{P} 24$ & Electricity, gas, steam and air conditioning & 49.2 & 44.3 \\
\hline $\mathrm{P} 25$ & Natural water; water treatment and supply services & 40.4 & 37.6 \\
\hline P26 & Sewerage services; sewage sludge; waste collection, treatment & 38.7 & 35.9 \\
\hline P27 & Constructions and construction works & 45.2 & 35.9 \\
\hline P28 & Wholesale and retail trade and repair services of motor vehicles & 32.2 & 31.1 \\
\hline P29 & Wholesale trade services, except for motor vehicles & 34.8 & 32.2 \\
\hline P30 & Retail trade services, except for motor vehicles and motorcycles & 32.7 & 31.6 \\
\hline P31 & Land transport services and transport services via pipelines & 43.7 & 36.9 \\
\hline P32 & Water transport services & 28.4 & 22.6 \\
\hline P33 & Air transport services & 32.9 & 24.4 \\
\hline P34 & Warehousing and support services for transportation & 47.9 & 36.9 \\
\hline P35 & Postal and courier services & 51.7 & 43.9 \\
\hline P36 & Accommodation and food services & 25.1 & 22.3 \\
\hline P37 & Publishing services & 38.5 & 42.2 \\
\hline P38 & Motion picture, video and television program production ... & 32.0 & 26.0 \\
\hline P39 & Telecommunications services & 42.8 & 38.6 \\
\hline $\mathrm{P} 40$ & Computer programming, consultancy and related services & 31.1 & 26.8 \\
\hline P41 & Financial services, except insurance and pension funding & 42.4 & 48.1 \\
\hline
\end{tabular}


Table 5 (continued)

\begin{tabular}{|c|c|c|c|}
\hline \multirow[t]{3}{*}{ Code SNA } & \multirow[t]{3}{*}{ Products } & \multicolumn{2}{|c|}{ Lockdown effect } \\
\hline & & \multicolumn{2}{|l|}{ Loss $\%$} \\
\hline & & SMEs & Large \\
\hline P42 & Insurance, reinsurance and pension funding services & 39.7 & 43.8 \\
\hline $\mathrm{P} 43$ & Services auxiliary to financial services and insurance services & 40.7 & 41.9 \\
\hline P44 & Real estate services & 49.0 & 42.3 \\
\hline $\mathrm{P} 45$ & Legal and accounting services; services of head offices & 49.0 & 39.1 \\
\hline P46 & Architectural and engineering services; technical testing & 46.9 & 36.8 \\
\hline P47 & Scientific research and development services & 34.6 & 28.7 \\
\hline P48 & Advertising and market research services & 56.7 & 42.1 \\
\hline P49 & Other professional, scientific and technical services; veterinary & 51.4 & 46.2 \\
\hline P50 & Rental and leasing services & 56.9 & 46.8 \\
\hline P51 & Employment services & 53.9 & 43.3 \\
\hline P52 & Travel agency, tour operator and other reservation services & 34.0 & 27.8 \\
\hline P53 & Security and investigation services; services to buildings & 47.8 & 43.8 \\
\hline P54 & Public administration and defense services; compulsory social secutiry & 13.0 & 12.9 \\
\hline P55 & Education services & 13.0 & 12.9 \\
\hline P56 & Private human health services & 35.4 & 49 \\
\hline P57 & Residential care services; social work services without accommodation & 16.8 & 18.0 \\
\hline P58 & Creative, arts and entertainment services; library, museum & 30.0 & 28.4 \\
\hline P59 & Sporting services and amusement and recreation services & 39.6 & 33.8 \\
\hline P60 & Services furnished by membership organizations & 52 & 43.2 \\
\hline P61 & Repair services of computers and personal and household goods & 42.4 & 46.8 \\
\hline P62 & Other personal services & 40.8 & 40.7 \\
\hline P63 & Services of households as employers & 37.3 & 40.0 \\
\hline
\end{tabular}

Note: The partial extraction is based on the share of essential activities allowed to provided services during the lockdown, according to RD 10/2020 of March 29.

Source: Own calculation.

activity shows greater sensitivity to the behavior of large firms, employment depends substantially on SMEs in general and microenterprises in particular.

Like Carvalho (2014), we contend that the analysis of cascading liquidity shocks in a network of producers, which is part of the pioneering work of Kiyotaki and Moore (1997), has been consistently overlooked. The study of these amplification mechanisms and the investigation of endogenous network formation in the presence of propagation and cascade dynamics remain promising areas of research (Acemoglu et al. 2015b). Incorporating the financial system within an FSAM could be a step forward in that direction. Making the interconnections between institutional sectors and financial institutions explicit means it is possible to analyze the effects of the financial network structure and systemic risk more rigorously (Acemoglu et al. 2015a). Moreover, the attention to more disaggregate general equilibrium models with SMEs features suggests building models that allow the integration of the statistical SNA, starting from the individual units that make up the aggregated data. Having more detailed and complete databases means it will be possible to identify the effect of each idiosyncratic shock, not only from the sectoral perspective but also at a firm level.

\subsection{Policy implications}

Typically, the computable general equilibrium (CGE) models used for pandemic analyses have been explored 


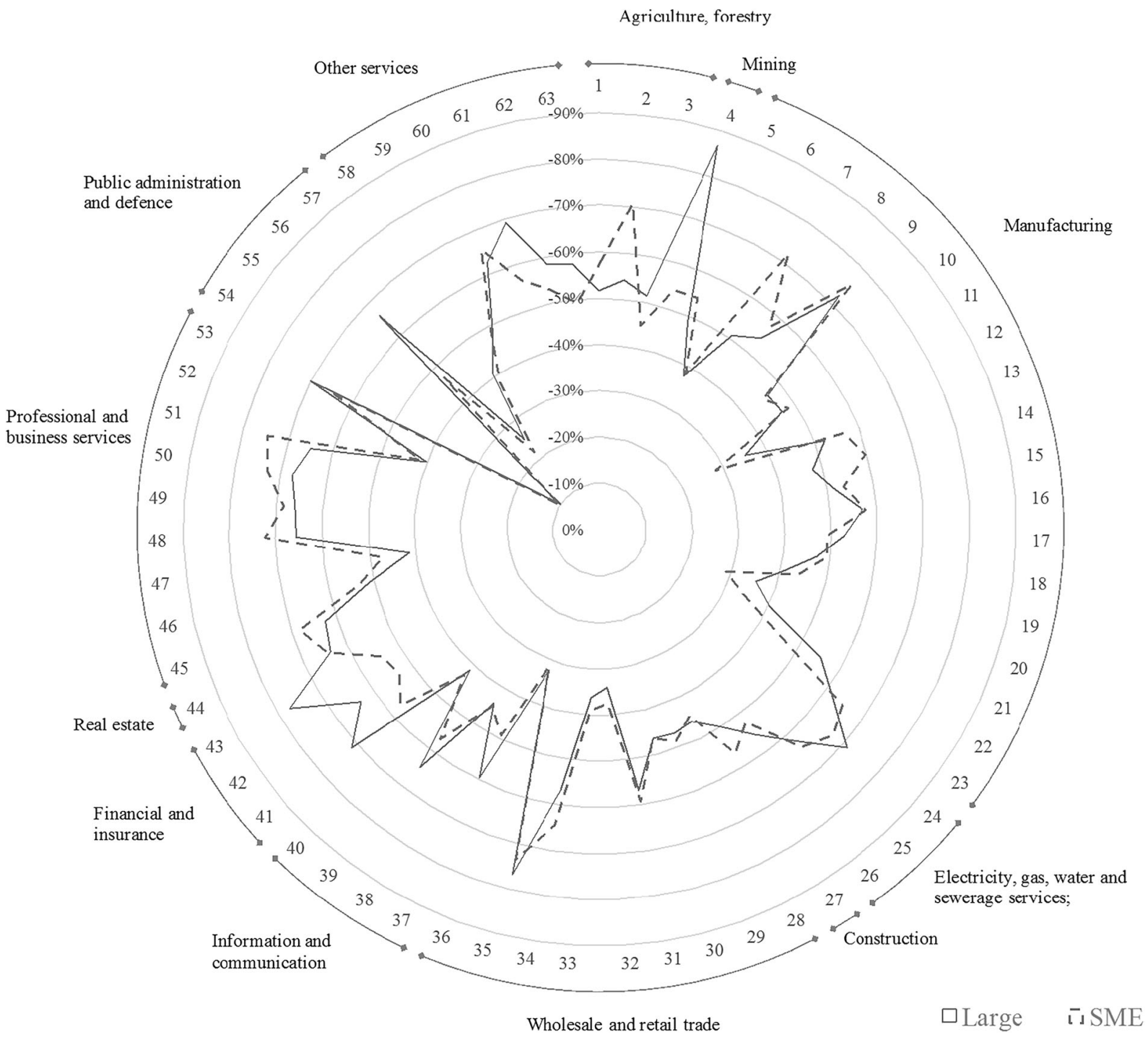

Fig. 1 Hypothetical extraction impact: total extraction of SMEs and large firms (\% loss in gross demand by products). The impact on demand by products is greater in SMEs $(52.17 \%)$ than in large firms $(47.83 \%)$. Source: Own calculation

through four channels: (1) the direct impact of a reduction in employment, (2) the increase in costs of international transactions, (3) the sharp drop in travel, and (4) the decline in demand for services that require proximity between people (Maryla and Aaditya 2020). Ending economic activities has simultaneous impacts on supply and demand, which requires the use of general balance models. Using the HEM (and following Dietzenbacher and Lahr 2013; Dietzenbacher and Miller 2015), we estimate the effects of the closure of nonessential businesses on the aggregate economic activity taking into account, simultaneously, the four channels described above.
Beyond the analysis of COVID-19 lockdown effects, joint analysis of SMEs in a CGE model opens up a greater set of analytical possibilities for the study of sectoral or industrial policies. Policies aimed at SMEs target economic achievements in terms of new job creation. As documented by prior studies, in policy actions, we "may find various activities, including trainings and education, advisory services and counseling or direct financial support distributed through financial instruments (soft loans and credit guarantees) and capital grants/subsidies" (Dvouletý et al. 2020). While such public policy interventions are aimed at coping with different market failures, empirical evidence shows that 
Agriculture, forestry

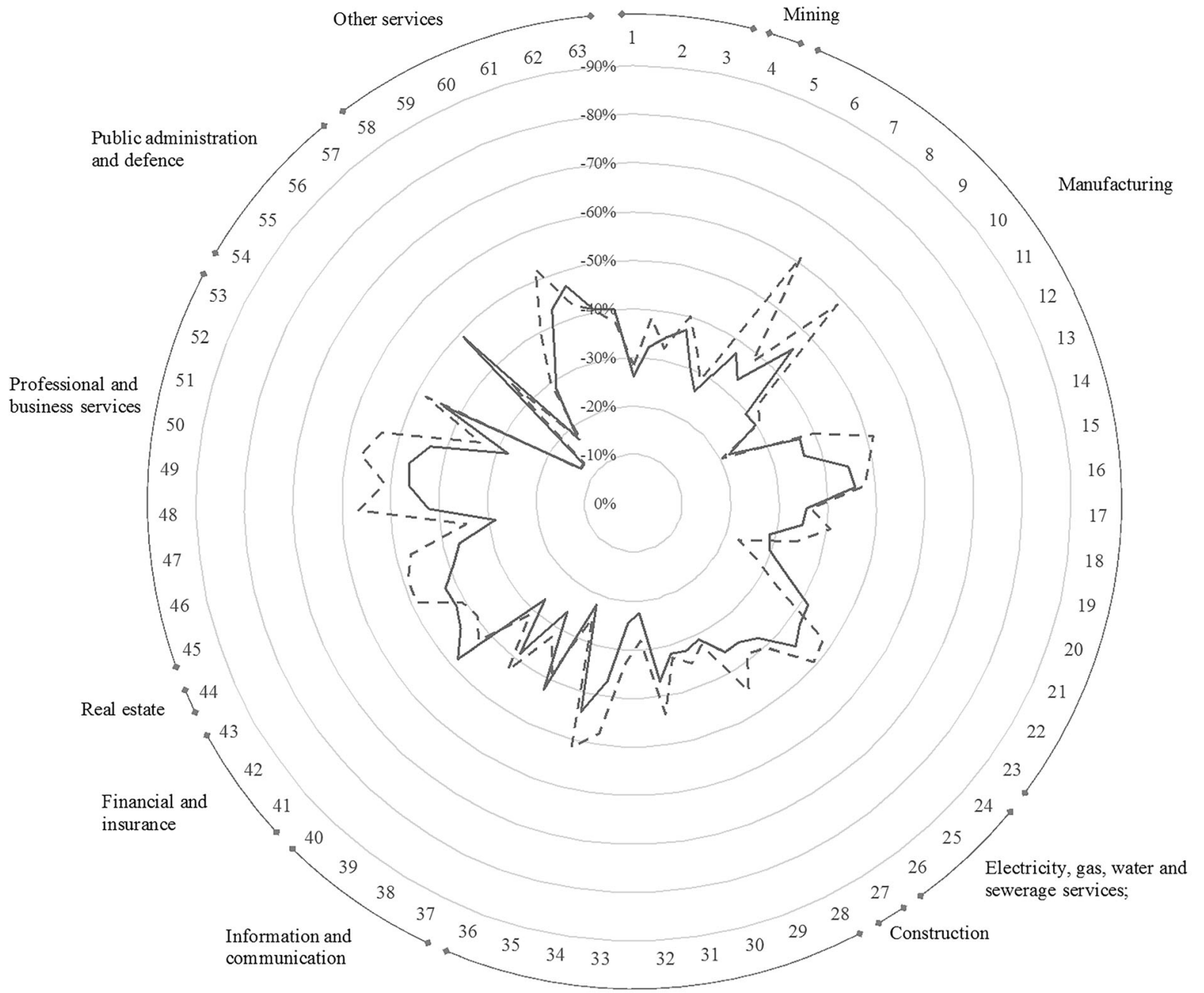

Wholesale and retail trade

Large

$\backsim \mathrm{SME}$

Fig. 2 Hypothetical extraction impact: partial extraction of SMEs and large firms caused by the lockdown (\% loss in gross demand by products). The impact on demand by products is greater in SMEs $(73.91 \%)$ than in large firms (26.09\%). Source: Own calculation

only a small percentage of firms contribute to creating employment (Dvouletý et al. 2019). An intense debate has emerged during the last year around the idea of whether such public policy actions and funding schemes should be allocated directly to the firms creating employment compared to current designs for all firms (e.g., Audretsch and Link 2019; Fotopoulos and Storey 2019). While some authors suggest that the outcomes of these policies are questionable and their usage should be substantially reduced (e.g., Åstebro 2017; Mason and Brown 2013; Shane 2009), another thread of the literature contends that the assessment of specific policies is necessary to formulate the best policy practices driven by empirical evidence (Acs et al. 2016; Dvouletý et al. 2019).

SMEs are an important focus of business support policies within the EU (De Man et al. 2016; Dvouletý and Lukeš 2017). So, for example, a first approximation shows that much of the contribution to the maintenance of economic activity comes from the financial sector. According to our estimations, disruptions in these firms produce bigger declines in demand. These results could support credit policies for SMEs with a strong impact on GDP due to their greater productive and financial 
Table 6 Hypothetical Extraction Impact: Partial Extraction of SMEs and Large Firms Caused by the Lockdown (\% loss in main aggregates)

\begin{tabular}{|c|c|c|c|c|}
\hline Firm size category & Direct & Indirect & Induced & Total effects \\
\hline \multicolumn{5}{|c|}{ D.1 Compensation of employees } \\
\hline SMEs & 4.64 & 2.04 & 0.28 & 7.01 \\
\hline Microenterprises & 1.42 & 0.66 & 0.09 & 2.19 \\
\hline Small enterprises & 1.72 & 0.75 & 0.10 & 2.59 \\
\hline Medium enterprises & 1.50 & 0.63 & 0.09 & 2.23 \\
\hline Large enterprises & 10.19 & 2.29 & 0.29 & 12.71 \\
\hline Total impact & 14.82 & 4.33 & 0.57 & 19.73 \\
\hline \multicolumn{5}{|c|}{ B.2b Operation surplus, gross/mixed income, gross } \\
\hline SMEs & 6.52 & 3.28 & 0.71 & 10.51 \\
\hline Microenterprises & 2.17 & 1.13 & 0.25 & 3.55 \\
\hline Small enterprises & 2.63 & 1.31 & 0.28 & 4.23 \\
\hline Medium enterprises & 1.71 & 0.84 & 0.18 & 2.73 \\
\hline Large enterprises & 6.12 & 2.93 & 0.58 & 9.63 \\
\hline Total impact & 12.64 & 6.21 & 1.28 & 20.14 \\
\hline \multicolumn{5}{|c|}{ B.1b Gross value added at basic prices } \\
\hline SMEs & 4.96 & 2.36 & 0.43 & 7.76 \\
\hline Microenterprises & 1.59 & 0.79 & 0.14 & 2.54 \\
\hline Small enterprises & 1.93 & 0.91 & 0.16 & 3.01 \\
\hline Medium enterprises & 1.43 & 0.65 & 0.12 & 2.21 \\
\hline Large enterprises & 7.43 & 2.33 & 0.39 & 10.13 \\
\hline Total impact & 12.39 & 4.68 & 0.82 & 17.89 \\
\hline
\end{tabular}

The partial extraction is based on the share of essential activities allowed to provided services during the lockdown, according to RD 10/2020 of March 29

Source: Own calculation

linkages with the domestic economy. Some evidence for the Spanish economy shows that guarantees had a strong effect on microenterprises (those with $<10$ employees) and also on small companies (those with $<50$ employees) (Martín-García and Santor 2021). The sectoral firm size multiplier analysis from the FSAM matrix contributes to explaining these results. From the perspective of policy designs, these results also enrich the idea of public policy guarantees as a mechanism that allows the relaxation of credit constraints, driving turnover and investment during both recession and growth (in line with Martín-García and Santor 2021).

The impact of this policy has varied widely across countries and has signified a high volume of subsidies in some cases (Honohan 2010). The evaluation of credit guarantees implies monitoring the overtime worked by program beneficiaries at the aggregated level. We should first consider how many of the supported firms survive over time (i.e., survival analysis in macroeconomic context) and then the number of cases (percentage shares) in which a government had to repay the guarantees (Dvouletý et al. 2019). This can only be done with the better collection and processing of microdata. This could also allow for a more detailed analysis of the aggregate impact of industrial policies at firm level, which would simultaneously improve transparency and accountability in the use of public resources.

\subsection{Limitations and future research agenda}

The various facets in which SMEs could impact the economy at the aggregate level highlight the difficulties of finding simple and universal formulas for the potential impact of industrial policies. Through the macroeconomic lens of the general equilibrium approach, it is about the policy outcomes in different socioeconomic dimensions that are most important. In the first place, it is important to distinguish between the short- and longterm policy effects. Counterfactual scenarios that could measure the effect of specific policies through time require both dynamic versions of the structural models and reliable data gathered by public sector authorities.

In the second place, the normative analysis of which interventions work best for SMEs should provide a clear list of the different variables that could be pinpointed as policy objectives. For example, Dvouletý et al. (2020) identify positive outcomes for grants regarding firm survival, employment, tangible/fixed assets, and sales/ turnover but find mixed results for labor productivity and total factor productivity. Qualifying one policy as superior to another requires a more general argumentation than a simple focus on activity, employment, or productivity.

In sum, it might be intuitive and natural to support firms during pandemics, but it is also necessary to consider the target variables and the actual effects of the policy and taxpayer's money. This is even more important when well-intended public policies to support companies could go wrong (Acs et al. 2016). Any welfare analysis leading to specific recommendations should consider the impact of large industries on the environment, competitiveness, governability, and even political stability. This could provide a more holistic argumentation that also considers the dark side and threats of different firm size categories and their potential threats. 
This paper also presents some drawbacks that serve, in turn, as promising avenues for future research. Our analysis incorporates both the real and financial spheres; however, while the detailed disaggregation of SMEs and large firms in the real sphere has been obtained from the recent structural business survey (Instituto Nacional de Estadística (INE) 2019), the financial sphere has been incorporated as a joint phenomenon involving SMEs and large firms (our model does not distinguish across differences in financial resources for SMEs and large firms). We are aware that SMEs need access to a range of financial instruments different from those of large firms to unleash their full potential to contribute to inclusive economic growth. Although data gaps in SME finances remain prominent (OECD 2019), future analyses could work to improve the collection of data and evidence regarding SME finances for its incorporation into our model.

Our analysis focuses on Spain, which was characterized both by strict confinement measures affecting economic activity (e.g., involving the cessation of nonessential economic activities for several weeks) and one of the highest infection rates worldwide. Although our model may be methodologically applicable to other countries, we call for caution when extrapolating our conclusions to SMEs and large firms in other countries, where policy-makers have adopted more relaxed decisions to cope with the COVID-19 pandemic. There is a need for additional empirical analyses covering other geographical zones to shed light on the effect of different governmental lockdown measures at the firm level.

We contend that this paper may also serve as an empirical reference to enhance debate in the EU on the effectiveness of national and EU funds supporting SMEs (Dvouletý et al. 2020) and may provide evidence that could inform policy and change how public programs are managed. It is important to note that while large firms receive the majority of public funding, methodological difficulties mean that evaluation of the effect of government-sponsored programs mainly focuses on SMEs. Many arguments are put forward to justify the focus of evaluation studies on SMEs, and it is often argued that smaller firms face greater obstacles to innovation while being important job generators. Nonetheless, large firms face a higher risk of opportunistic behavior when receiving public funding (Autant-Bernard et al. 2020). Applied to SMEs, guarantees are, for example, more efficient than subsidies, because some of the money is returned to the guarantee provider and can thus be used again. However, "if the entrepreneurs and firm-owners borrow more resources than they need, over debt themselves and bankrupt, then the public funds are lost" (Dvouletý et al. 2019: p. 2). Future research is needed in Spain in terms of (a) survival analyses in the macroeconomic context, investigating how many of the SMEs supported during the lockdown guarantees survived over time, and (b) in how many cases the government had to repay the guarantees (e.g., Dvouletý et al. 2019).

Our empirical findings suggest that the proposed model reasonably quantifies the effects of the COVID-19 lockdown on economic activity. Dealing with theoretical structures that consider the links between shocks at the idiosyncratic level and their aggregate impact, it is possible to measure not only sectoral problems and those issues related to the labor market or economic growth but also the relative importance of SMEs in the overall results. This paper thus provides clues about possible extensions that could lead to more detailed industrial policy recommendations. Although there is little empirical analysis elsewhere (Dvouletý et al. 2019), this study offers new insights into the data and transmission mechanisms that should be studied to increase our understanding of the effects of SME support policies.

Although specific policy analysis is beyond the scope of this paper, we believe that the theoretical framework could be adapted to review, from a renewed general equilibrium perspective, the analysis of public policy support to SMEs. The intermediate approach between firm-level analysis and macroeconomic aggregation can be used to consider some of the misunderstood effects of different industrial policies such as soft loans, direct subsidies, fiscal incentives, public venture capital programs, entrepreneurial training, entrepreneurship education, and payable and nonrepayable capital grants. Naturally, this evaluation cannot be done directly without recognizing the analytical particularities of each policy setting. 


\section{Appendix}

Table 7 Distribution (number and employees) of firms by size and activities in Social Accounting Matrices in Spain (2016)

\begin{tabular}{|c|c|c|c|c|c|}
\hline \multirow[t]{3}{*}{ Code SNA } & \multirow[t]{3}{*}{ Activities } & \multicolumn{2}{|l|}{ Firms } & \multicolumn{2}{|c|}{ Employees } \\
\hline & & \multicolumn{2}{|c|}{ Share in $\%$} & \multicolumn{2}{|c|}{ Share in $\%$} \\
\hline & & SMEs & Large & SMEs & Large \\
\hline A01 & Crop and animal production, hunting and related activities & 99.9 & 0.1 & 90.6 & 9.4 \\
\hline $\mathrm{A} 02$ & Forestry and logging & 99.9 & 0.1 & 90.6 & 9.4 \\
\hline $\mathrm{A} 03$ & Fishing and aquaculture & 99.9 & 0.1 & 90.6 & 9.4 \\
\hline A04 & Mining and quarrying & 96.6 & 3.4 & 86.4 & 13.6 \\
\hline A05 & Manufacture of food products, beverages and tobacco products & 99.1 & 0.9 & 68.6 & 31.4 \\
\hline A06 & Manufacture of textiles, wearing apparel and leather products & 94.8 & 5.2 & 90.8 & 9.2 \\
\hline A07 & Manufacture of wood and products of wood and cork & 99.9 & 0.1 & 93.0 & 7.0 \\
\hline A08 & Manufacture of paper and paper products & 98.5 & 1.5 & 69.8 & 30.2 \\
\hline A09 & Printing and reproduction of recorded media & 99.9 & 0.1 & 95.8 & 4.2 \\
\hline A10 & Manufacture of coke and refined petroleum products & 22.2 & 77.8 & 3.6 & 96.4 \\
\hline A11 & Manufacture of chemicals and chemical products & 98.4 & 1.6 & 66.8 & 33.2 \\
\hline A12 & Manufacture of basic pharmaceutical product & 86.3 & 13.7 & 25.6 & 74.4 \\
\hline A13 & Manufacture of rubber and plastic products & 99.1 & 0.9 & 70.1 & 29.9 \\
\hline A14 & Manufacture of other non-metallic mineral products & 99.4 & 0.6 & 72.8 & 27.2 \\
\hline A15 & Manufacture of basic metals & 96.2 & 3.8 & 44.5 & 55.5 \\
\hline A16 & Manufacture of fabricated metal products & 99.8 & 0.2 & 88.5 & 11.5 \\
\hline A17 & Manufacture of computer, electronic and optical products & 99.3 & 0.7 & 76.3 & 23.7 \\
\hline A18 & Manufacture of electrical equipment & 98.2 & 1.8 & 44.3 & 55.7 \\
\hline A19 & Manufacture of machinery and equipment n.e.c. & 99.3 & 0.7 & 78.1 & 21.9 \\
\hline A20 & Manufacture of motor vehicles, trailers and semi-trailers & 94.0 & 6.0 & 24.8 & 75.2 \\
\hline A21 & Manufacture of other transport equipment & 96.8 & 3.2 & 28.0 & 72.0 \\
\hline $\mathrm{A} 22$ & Manufacture of furniture; other manufacturing & 99.9 & 0.1 & 89.8 & 10.2 \\
\hline $\mathrm{A} 23$ & Repair and installation of machinery and equipment & 99.8 & 0.2 & 76.2 & 23.8 \\
\hline A24 & Electricity, gas, steam and air conditioning supply & 99.8 & 0.2 & 37.7 & 62.3 \\
\hline A25 & Water collection, treatment and supply & 87.3 & 12.7 & 31.8 & 68.2 \\
\hline A26 & Sewerage; waste collection, treatment and disposal activities & 95.3 & 4.7 & 35.8 & 64.2 \\
\hline A27 & Construction & 99.9 & 0.1 & 90.2 & 9.8 \\
\hline A28 & Wholesale and retail trade and repair of motor vehicles & 99.9 & 0.1 & 97.5 & 2.5 \\
\hline A29 & Wholesale trade, except for motor vehicles and motorcycles & 99.9 & 0.1 & 84.8 & 15.2 \\
\hline A30 & Retail trade, except for motor vehicles and motorcycles & 99.9 & 0.1 & 67.0 & 33.0 \\
\hline A31 & Land transport and transport via pipelines & 99.9 & 0.1 & 91.1 & 8.9 \\
\hline A 32 & Water transport & 99.9 & 0.1 & 20.0 & 80.0 \\
\hline A 33 & Air transport & 28.9 & 71.1 & 0.7 & 99.3 \\
\hline A34 & Warehousing and support activities for transportation & 99.4 & 0.6 & 58.9 & 41.1 \\
\hline A35 & Postal and courier activities & 99.9 & 0.1 & 46.6 & 53.4 \\
\hline A36 & Accommodation; food and beverage service activities & 99.9 & 0.1 & 88.4 & 11.6 \\
\hline
\end{tabular}


Table 7 (continued)

\begin{tabular}{|c|c|c|c|c|c|}
\hline \multirow[t]{3}{*}{ Code SNA } & \multirow[t]{3}{*}{ Activities } & \multicolumn{2}{|l|}{ Firms } & \multicolumn{2}{|c|}{ Employees } \\
\hline & & \multicolumn{2}{|c|}{ Share in $\%$} & \multicolumn{2}{|c|}{ Share in \% } \\
\hline & & SMEs & Large & SMEs & Large \\
\hline A37 & Publishing activities & 99.8 & 0.2 & 76.9 & 23.1 \\
\hline A38 & Motion picture, video and television program production & 99.7 & 0.3 & 44.6 & 55.4 \\
\hline A39 & Telecommunications & 98.8 & 1.2 & 42.3 & 57.7 \\
\hline A40 & Computer programming, consultancy and related activities & 99.5 & 0.5 & 53.6 & 46.4 \\
\hline A41 & Financial service activities, except insurance and pension & 0.0 & 100 & 0.0 & 100 \\
\hline A42 & Insurance, reinsurance and pension except social security & 0.0 & 100 & 0.0 & 100 \\
\hline A43 & Activities auxiliary to financial services and insurance activities & 0.0 & 100 & 0.0 & 100 \\
\hline A44 & Real estate activities & 99.9 & 0.1 & 98.3 & 1.7 \\
\hline A45 & Legal and accounting activities; activities of head offices & 99.9 & 0.1 & 87.7 & 12.3 \\
\hline A46 & Architectural and engineering activities; technical testing & 99.9 & 0.1 & 76.8 & 23.2 \\
\hline A47 & Scientific research and development & 99.5 & 0.5 & 30.8 & 69.2 \\
\hline A48 & Advertising and market research & 99.9 & 0.1 & 83.1 & 16.9 \\
\hline A49 & Other professional, scientific and technical activities; veterinary & 99.9 & 0.1 & 84.0 & 16.0 \\
\hline A50 & Rental and leasing activities & 99.9 & 0.1 & 87.4 & 12.6 \\
\hline A51 & Employment activities & 97.6 & 2.4 & 14.0 & 86.0 \\
\hline A52 & Travel agency, tour operator reservation service & 99.9 & 0.1 & 100.0 & 0.0 \\
\hline A53 & Security and investigation activities; services to buildings & 99.6 & 0.4 & 43.0 & 57.0 \\
\hline A54 & Public administration and defense; compulsory social security & - & 100 & - & 100 \\
\hline A55 & Education & - & 100 & - & 100 \\
\hline A56 & Human health activities & - & 100 & - & 100 \\
\hline A57 & Social work activities & 99.9 & 0.1 & 89.6 & 10.4 \\
\hline A58 & Creative, arts and entertainment activities; libraries, museums & 99.9 & 0.1 & 88.3 & 11.7 \\
\hline A59 & Sports activities and amusement and recreation activities & 99.9 & 0.1 & 88.8 & 11.2 \\
\hline A60 & Activities of membership organizations & 100 & - & 100 & - \\
\hline A61 & Repair of computers and personal and household goods & 99.9 & 0.1 & 86.0 & 14.0 \\
\hline A62 & Other personal service activities & 99.9 & 0.1 & 97.0 & 3.0 \\
\hline A63 & Activities of households as employers & 100 & - & 100 & - \\
\hline
\end{tabular}

Source: Own calculations based on the Annual Spanish National Accounts (2019 Benchmark Revision) and the results of the Project of Integration of Structural Business Statistics (INE, 2019) 
Table 8 Share (\%) of essential activities allowed to provided services during the lockdown. According to RD 10/2020 of March 29

\begin{tabular}{|c|c|c|}
\hline Code SNA & Activities & Share $(\%)$ of essential activity \\
\hline A01 & Crop and animal production, hunting and related activities & 99.6 \\
\hline A02 & Forestry and logging & 100 \\
\hline A03 & Fishing and aquaculture & 100 \\
\hline A04 & Mining and quarrying & 0.0 \\
\hline A05 & Manufacture of food products, beverages and tobacco products & 100 \\
\hline A06 & Manufacture of textiles, wearing apparel and leather products & 64.4 \\
\hline A07 & Manufacture of wood and products of wood and cork & 32.6 \\
\hline A08 & Manufacture of paper and paper products & 83.0 \\
\hline A09 & Printing and reproduction of recorded media & 0.0 \\
\hline A 10 & Manufacture of coke and refined petroleum products & 99.6 \\
\hline A11 & Manufacture of chemicals and chemical products & 91.7 \\
\hline A12 & Manufacture of basic pharmaceutical product & 100 \\
\hline A13 & Manufacture of rubber and plastic products & 86.4 \\
\hline A14 & Manufacture of other non-metallic mineral products & 0.0 \\
\hline A15 & Manufacture of basic metals & 0.0 \\
\hline A16 & Manufacture of fabricated metal products & 0.0 \\
\hline A17 & Manufacture of computer, electronic and optical products & 95.0 \\
\hline A18 & Manufacture of electrical equipment & 69.1 \\
\hline A19 & Manufacture of machinery and equipment n.e.c. & 0.0 \\
\hline A20 & Manufacture of motor vehicles, trailers and semi-trailers & 0.0 \\
\hline A 21 & Manufacture of other transport equipment & 0.0 \\
\hline A 22 & Manufacture of furniture; other manufacturing & 69.7 \\
\hline A23 & Repair and installation of machinery and equipment & 42.5 \\
\hline A24 & Electricity, gas, steam and air conditioning supply & 97.0 \\
\hline A 25 & Water collection, treatment and supply & 100 \\
\hline A26 & Sewerage; waste collection, treatment and disposal activities & 100 \\
\hline A 27 & Construction & 27.0 \\
\hline A28 & Wholesale and retail trade and repair of motor vehicles & 54.3 \\
\hline A29 & Wholesale trade, except of motor vehicles and motorcycles & 59.5 \\
\hline A 30 & Retail trade, except of motor vehicles and motorcycles & 62.2 \\
\hline A 31 & Land transport and transport via pipelines & 70.3 \\
\hline A 32 & Water transport & 36.6 \\
\hline A 33 & Air transport & 3.2 \\
\hline A34 & Warehousing and support activities for transportation & 74.1 \\
\hline A 35 & Postal and courier activities & 100 \\
\hline A 36 & Accommodation; food and beverage service activities & 57.7 \\
\hline A 37 & Publishing activities & 31.0 \\
\hline A 38 & Motion picture, video and television program production & 100 \\
\hline A39 & Telecommunications & 100 \\
\hline A40 & Computer programming, consultancy and related activities & 79.6 \\
\hline A41 & Financial service activities, except for insurance and pension & 94.6 \\
\hline A 42 & Insurance, reinsurance and pension except for social security & 98.9 \\
\hline A43 & Activities auxiliary to financial services and insurance activities & 100 \\
\hline A44 & Real estate activities & 0.0 \\
\hline
\end{tabular}


Table 8 (continued)

\begin{tabular}{|c|c|c|}
\hline Code SNA & Activities & Share $(\%)$ of essential activity \\
\hline A45 & Legal and accounting activities; activities of head offices & 100 \\
\hline A46 & Architectural and engineering activities; technical testing & 22.5 \\
\hline A47 & Scientific research and development & 95.1 \\
\hline A48 & Advertising and market research & 0.0 \\
\hline A49 & Other professional, scientific and technical activities; veterinary & 85.8 \\
\hline A50 & Rental and leasing activities & 32.2 \\
\hline A51 & Employment activities & 0.0 \\
\hline A52 & Travel agency, tour operator reservation service & 0.0 \\
\hline A53 & Security and investigation activities; services to buildings & 90.4 \\
\hline A54 & Public administration and defense; compulsory social security & 90.1 \\
\hline A55 & Education & 0.0 \\
\hline A56 & Human health activities & 95.1 \\
\hline A57 & Social work activities & 28.4 \\
\hline A58 & Creative, arts and entertainment activities; libraries, museums & 0.0 \\
\hline A59 & Sports activities and amusement and recreation activities & 0.0 \\
\hline A60 & Activities of membership organizations & 0.0 \\
\hline A61 & Repair of computers and personal and household goods & 23.5 \\
\hline A62 & Other personal service activities & 44.6 \\
\hline A63 & Activities of households as employers & 0.0 \\
\hline
\end{tabular}

Source: According to RD 10/2020 of March 29

Acknowledgements We are grateful for the valuable comments and suggestions received from two anonymous reviewers, and for the outstanding developmental guidance throughout the reviewing process from SBE Editorial Board. This work was supported by the Spanish Ministry of Science and Innovation (MICINN) [grant number: PID2019-106725GB-I00].

\section{References}

Acemoglu, D., \& Azar, P. D. (2020). Endogenous production networks. Econometrica, 88(1), 33-82. https://doi. org/10.3982/ECTA15899.

Acemoglu, D., Carvalho, V. M., Ozdaglar, A., \& Tahbaz-Salehi, A. (2012). The network origins of aggregate fluctuations. Econometrica, 80(5), 1977-2016. https://doi.org/10.3982 /ECTA9623.

Acemoglu, D., Ozdaglar, A., \& Tahbaz-Salehi, A. (2015a). Systemic risk and stability in financial networks. American Economic Review, 105(2), 564-608. https://doi.org/10.1257 /aer.20130456.

Acemoglu, D., Ozdaglar, A., \& Tahbaz-Salehi, A. (2015b). Networks, shocks, and systemic risk. Cambridge: National Bureau of Economic Research. https://doi.org/10.1093 /oxfordhb/9780199948277.013.17.
Acemoglu, D., Akcigit, U., \& Kerr, W. (2016). Networks and the macroeconomy: An empirical exploration. NBER Macroeconomics Annual, 30(1), 273-335. https://doi. org/10.1086/685961.

Acemoglu, D., Ozdaglar, A., \& Tahbaz-Salehi, A. (2017). Microeconomic origins of macroeconomic tail risks. American Economic Review, 107(1), 54-108. https://doi. org/10.1257/aer.20151086.

Acs, Z., Åstebro, T., Audretsch, D., \& Robinson, D. T. (2016). Public policy to promote entrepreneurship: A call to arms. Small Business Economics, 47(1), 35-51. https://doi. org/10.1007/s11187-016-9712-2.

Acs, Z. J., Estrin, S., Mickiewicz, T., \& Szerb, L. (2018). Entrepreneurship, institutional economics, and economic growth: An ecosystem perspective. Small Business Economics, 51(2), 501-514. https://doi.org/10.1007 /s11187-018-0013-9.

Aray, H., Pedauga, L., \& Velázquez, A. (2017). Financial social accounting matrix: A useful tool for understanding the macro-financial linkages of an economy. Economic Systems Research, 29(4), 486-508. https://doi.org/10.1080 /09535314.2017.1365049.

Åstebro, T. (2017). The private financial gains to entrepreneurship: Is it a good use of public money to encourage individuals to become entrepreneurs? Small Business Economics, 48(2), 323-329. https://doi.org/10.1007/s11187-016-9777-y. 
Atalay, E. (2017). How important are sectoral shocks? American Economic Journal: Macroeconomics, 9(4), 254-280. https://doi.org/10.1257/mac.20160353.

Audretsch, D. B., \& Link, A. N. (2019). Embracing an entrepreneurial ecosystem: An analysis of the governance of research joint ventures. Small Business Economics, 52(2), 429-436. https://doi.org/10.1007/s11187-017-9953-8.

Audretsch, D. B., Carree, M. A., \& Thurik, A. R. (2001). Does entrepreneurship reduce unemployment? Tinbergen Institute Discussion Paper, No. 01-074/3. Amsterdam and Rotterdam: Tinbergen Institute.

Audretsch, D. B., Belitski, M., \& Desai, S. (2015). Entrepreneurship and economic development in cities. The Annals of Regional Science, 55(1), 33-60. https://doi. org/10.1007/s00168-015-0685-x.

Autant-Bernard, C., Fotso, R., \& Massard, N. (2020). Evaluating the impact of public policies on large firms: A synthetic control approach to science industry transfer policies. GATE WP 2018 - May 2020. DOI: https://doi.org/10.2139 /ssrn.3619007.

Ayyagari, M., Beck, T., \& Demirguc-Kunt, A. (2007). Small and medium enterprises across the globe. Small Business Economics, 29(4), 415-434. https://doi.org/10.1596/18139450-3127.

Ayyagari, M., Demirguc-Kunt, A., \& Maksimovic, V. (2011). Small vs. young firms across the world: Contribution to employment, job creation, and growth. Washington, DC: World Bank. https://doi.org/10.1596/1813-9450-5631.

Baas, T., \& Schrooten, M. (2006). Relationship banking and SMEs: A theoretical analysis. Small Business Economics, 27(2-3), 127-137. https://doi.org/10.1007/s11187-0060018-7.

Baker, S. R., Bloom, N., Davis, S. J., \& Terry, S. J. (2020). COVID-induced economic uncertainty (No. w26983). Cambridge: National Bureau of Economic Research.

Baptista, R., \& Thurik, A. R. (2007). The relationship between entrepreneurship and unemployment: Is Portugal an outlier? Technological Forecasting and Social Change, 74(1), 7589. https://doi.org/10.1016/j.techfore.2006.04.003.

Bartik, A. W., Bertrand, M., Cullen, Z., Glaeser, E. L., Luca, M., \& Stanton, C. (2020). The impact of COVID-19 on small business outcomes and expectations. Proceedings of the National Academy of Sciences, 117(30), 17656-17666. https://doi.org/10.1073/pnas.2006991117.

Beck, T., Demirguc-Kunt, A., \& Levine, R. (2005). SMEs, growth, and poverty: Cross-country evidence. Journal of Economic Growth, 10(3), 199-229. https://doi.org/10.1007 /s10887-005-3533-5.

Belitski, M., Caiazza, R., \& Lehmann, E. E. (2019). Knowledge frontiers and boundaries in entrepreneurship research. Small Business Economics. https://doi.org/10.1007/s11187-01900187-0.

Bonfim, D. (2009). Credit risk drivers: Evaluating the contribution of firm level information and of macroeconomic dynamics. Journal of Banking and Finance, 33(2), 281-299. https://doi. org/10.1016/j.jbankfin.2008.08.006.

Bullough, A., \& Renko, M. (2013). Entrepreneurial resilience during challenging times. Business Horizons, 56(3), 343350. https://doi.org/10.1016/j.bushor.2013.01.001.
Burns, A., Van der Mensbrugghe, D., \& Timmer, H. (2006). Evaluating the economic consequences of avian influenza (p. 6). Washington, DC: World Bank.

Cadestin, C., De Backer, K., Miroudot, S., Moussiegt, L., Rigo, D., \& Ye, M. (2019). Multinational enterprises in domestic value chains. OECD Science, Technology and Industry Policy Papers, 2019/03, No. 63, France. DOI: https://doi. org/10.1787/9abfa931-en

Carvalho, V. M. (2014). From micro to macro via production networks. Journal of Economic Perspectives, 28(4), 23-48. https://doi.org/10.1257/jep.28.4.23.

Carvalho, V., \& Gabaix, X. (2013). The great diversification and its undoing. American Economic Review, 103(5), 16971727. https://doi.org/10.1257/aer.103.5.1697.

Coibion, O., Gorodnichenko, Y., \& Weber, M. (2020). The cost of the COVID-19 crisis: Lockdowns, macroeconomic expectations, and consumer spending. Cambridge: National Bureau of Economic Research. https://doi.org/10.2139 /ssrn.3593848.

De Man, P., Munters, W., \& Marx, A. (2016). Entrepreneurship policy: A multi-dimensional and multi-level assessment. Financial and Institutional Reforms for an Entrepreneurial [sic] Society. Lirias.

Defourny, J., \& Thorbecke, E. (1984). Structural path analysis and multiplier decomposition within a social accounting matrix framework. The Economic Journal, 94(373), 111-136. https://doi.org/10.2307/2232220.

Di Giovanni, J., Levchenko, A. A., \& Mejean, I. (2014). Firms, destinations, and aggregate fluctuations. Econometrica, 82(4), 1303-1340. https://doi.org/10.3982/ECTA11041.

Dietzenbacher, E., \& Lahr, M. L. (2013). Expanding extractions. Economic Systems Research, 25(3), 341-360. https://doi. org/10.1080/09535314.2013.774266.

Dietzenbacher, E., \& Miller, R. E. (2015). Reflections on the inoperability input-output model. Economic Systems Research, 27(4), 478-486. https://doi.org/10.1080 /09535314.2015.1052375.

Dietzenbacher, E., van Burken, B., \& Kondo, Y. (2019). Hypothetical extractions from a global perspective. Economic Systems Research, 31(4), 505-519. https://doi. org/10.1080/09535314.2018.1564135.

Dixon, P. B., Lee, B., Muehlenbeck, T., Rimmer, M. T., Rose, A., \& Verikios, G. (2010). Effects on the US of an H1N1 epidemic: Analysis with a quarterly CGE model. Journal of Homeland Security and Emergency Management, 7(1), 128. https://doi.org/10.2202/1547-7355.1769.

Dupor, B. (1999). Aggregation and irrelevance in multi-sector models. Journal of Monetary Economics, 43(2), 391-409. https://doi.org/10.1016/S0304-3932(98)00057-9.

Dvouletý, O., \& Lukeš, M. (2017). Report on policies on business startups and self-employment. Heidelberg: CUPESSE. https://doi.org/10.13140/RG.2.2.20256.89608/1.

Dvouletý, O., Čadil, J., \& Mirošník, K. (2019). Do firms supported by credit guarantee schemes report better financial results 2 years after the end of intervention? The BE Journal of Economic Analysis \& Policy, 19(1), 1-20. https://doi. org/10.1515/bejeap-2018-0057.

Dvouletý, O., Srhoj, S., \& Pantea, S. (2020). Public SME grants and firm performance in European Union: A systematic review of empirical evidence. Small Business Economics. https://doi.org/10.1007/s11187-019-00306-x. 
Ebeke, M. C. H., \& Eklou, K. M. (2017). The granular origins of macroeconomic fluctuations in Europe. Washington, DC: International Monetary Fund. https://doi.org/10.5089 /9781484324806.001.

El Haimar, A., \& Santos, J. R. (2015). A stochastic recovery model of influenza pandemic effects on interdependent workforce systems. Natural Hazards, 77(2), 987-1011. https://doi. org/10.1007/s11069-015-1637-6.

Emini, C. A., \& Fofack, H. (2004). A financial social accounting matrix for the integrated macroeconomic model for poverty analysis: Application to Cameroon with a fixed-price multiplier analysis. Vol. 3219. Washington, DC: World Bank Publications. https://doi.org/10.2139/ssrn.1393624.

European Commission (2019). 2019 SBA Fact Sheet for Spain: Internal Market, Industry, Entrepreneurship and SMEs. Brussels. Retrieved from https://ec.europa. $\mathrm{eu} / \mathrm{docsroom} / \mathrm{documents} / 38662 /$ attachments $/ 27$ /translations/en/renditions/native (accessed 01.12.20).

Farhi, E., \& Baqaee, D. R. (2020). Supply and demand in disaggregated Keynesian economies with an application to the COVID-19 crisis. Cambridge: National Bureau of Economic Research. https://doi.org/10.3386/w27152.

Foerster, A. T., Sarte, P. D. G., \& Watson, M. W. (2011). Sectoral versus aggregate shocks: A structural factor analysis of industrial production. Journal of Political Economy, 119(1), 138. https://doi.org/10.1086/659311.

Fotopoulos, G., \& Storey, D. J. (2019). Public policies to enhance regional entrepreneurship: Another programme failing to deliver? Small Business Economics, 53(1), 189-209. https://doi.org/10.1007/s11187-018-0021-9.

Freund, C., \& Pierola, M. D. (2015). Export superstars. Review of Economics and Statistics, 97(5), 1023-1032.

Gabaix, X. (2011). The granular origins of aggregate fluctuations. Econometrica, 79(3), 733-772.

Garicano, L., Lelarge, C., \& Van Reenen, J. (2016). Firm size distortions and the productivity distribution: Evidence from France. American Economic Review, 106(11), 3439-3479. https://doi.org/10.1257/aer.20130232.

Gersovitz, M., \& Hammer, J. S. (2004). The economical control of infectious diseases. The Economic Journal, 114(492), 1-27. https://doi.org/10.1046/j.0013-0133.2003.0174.x.

Gopinath, G. (2020). The great lockdown: Worst economic downturn since the Great Depression. IMF Blog-Insights \& Analysis on Economics \& Finance. Accesible from: https://blogs.imf.org/2020/04/14/the-great-lockdown-worsteconomic-downturn-since-the-great-depression/. Accessed 15 May 2020.

Guerra, A. I., \& Sancho, F. (2010). Measuring energy linkages with the hypothetical extraction method: An application to Spain. Energy Economics, 32(4), 831-837. https://doi. org/10.1016/j.eneco.2009.10.017.

Honohan, P. (2010). Partial credit guarantees: Principles and practice. Journal of Financial Stability, 6(1), 1-9. https://doi. org/10.1016/j.jfs.2009.05.008.

Horvath, M. (1998). Cyclicality and sectoral linkages: Aggregate fluctuations from independent sectoral shocks. Review of Economic Dynamics, 1(4), 781-808. https://doi.org/10.1006 /redy.1998.0028.

Horvath, M. (2000). Sectoral shocks and aggregate fluctuations. Journal of Monetary Economics, 45(1), 69-106. https://doi. org/10.1016/S0304-3932(99)00044-6.
Instituto Nacional de Estadística (INE). (2019). Estadística estructural de empresas: Sector industrial, sector comercio, sector servicios. Madrid: INE http://www.ine.es.

Jovanovic, B. (1987). Micro shocks and aggregate risk. The Quarterly Journal of Economics, 102(2), 395-409. https://doi.org/10.2307/1885069.

Keogh-Brown, M. R., Smith, R. D., Edmunds, J. W., \& Beutels, P. (2010). The macroeconomic impact of pandemic influenza: Estimates from models of the United Kingdom, France, Belgium and The Netherlands. The European Journal of Health Economics, 11(6), 543-554. https://doi.org/10.1007 /s10198-009-0210-1.

Kermack, W. O., \& McKendrick, A. G. (1927). A contribution to the mathematical theory of epidemics. Proceedings of the Royal Society of London. Series A, Containing Papers of a Mathematical and Physical Character, 115(772), 700-721. https://doi.org/10.1098/rspa.1927.0118.

Kersten, R., Harms, J., Liket, K., \& Maas, K. (2017). Small firms, large impact? A systematic review of the SME finance literature. World Development, 97, 330-348. https://doi. org/10.1016/j.worlddev.2017.04.012.

Kiyotaki, N., \& Moore, J. (1997). Credit cycles. Journal of Political Economy, 105(2), 211-248. https://doi. org/10.1086/262072.

Klein, E., Laxminarayan, R., Smith, D. L., \& Gilligan, C. A. (2007). Economic incentives and mathematical models of disease. Environment and Development Economics, 25(6), 707-732. https://doi.org/10.1017/S1355770X0700383X.

Koellinger, P. D., \& Roy Thurik, A. (2012). Entrepreneurship and the business cycle. Review of Economics and Statistics, 94(4), 1143-1156. https://doi.org/10.2139/ssrn.1403867.

Kotsopoulos, N., Haitsma, G., Connolly, M. P., \& Standaert, B. (2019). Estimating the money flow in the economy attributed to rotavirus disease and vaccination in the Netherlands using a Social Accounting Matrix (SAM) framework. Expert Review of Pharmacoeconomics \& Outcomes Research, 20(6), 603612. https://doi.org/10.1080/14737167.2020.1693269.

Lee, J. W., \& McKibbin, W. J. (2004). Globalization and disease: The case of SARS. Asian Economic Papers, 3(1), 113-131. https://doi.org/10.1162/1535351041747932.

Lehmann, E., \& Neuberger, D. (2001). Do lending relationships matter? Evidence from bank survey data in Germany. Journal of Economic Behavior \& Organization, 45(4), 339-359. https://doi.org/10.1016/S0167-2681(01)00151-2.

Long Jr., J. B., \& Plosser, C. I. (1983). Real business cycles. Journal of Political Economy, 91(1), 39-69. https://doi. org/10.1086/261128.

Martín-García, R., \& Santor, J. M. (2021). Public guarantees: A countercyclical instrument for SME growth. Evidence from the Spanish region of Madrid. Small Business Economics, 56(1), 427-449. https://doi.org/10.1007/s11187-019-002140.

Maryla, V. M., \& Aaditya, M. (2020). The potential impact of COVID-19 on GDP and trade: A preliminary assessment [working paper]. Washington, DC: The World Bank. https://doi.org/10.1596/1813-9450-9211.

Mason, C., \& Brown, R. (2013). Creating good public policy to support high-growth firms. Small Business Economics, 40(2), 211-225. https://doi.org/10.1007/s11187-011-9369-9.

Miller, R. E. (1966). Interregional feedback effects in input-output models: Some preliminary results. Papers of the Regional 
Science Association, 17(1), 105-125. https://doi.org/10.1111 /j.1435-5597.1966.tb01344.x.

Miller, R. E., \& Blair, P. D. (2009). Input-output analysis: Foundations and extensions. Cambridge: Cambridge University Press. https://doi.org/10.1017/CBO97805 11626982.003.

Miller, R. E., \& Lahr, M. L. (2001). A taxonomy of extractions. In M. L. Lahr \& R. E. Miller (Eds.), Regional science perspectives in economic analysis - A festschrift in memory of Benjamin H. Stevens (pp. 407-441). Amsterdam: Emerald Group.

Narjoko, D., \& Hill, H. (2007). Winners and losers during a deep economic crisis: Firm-level evidence from Indonesian manufacturing. Asian Economic Journal, 21(4), 343-368. https://doi.org/10.1111/j.1467-8381.2007.00261.x.

Nicola, M., Alsafi, Z., Sohrabi, C., Kerwan, A., Al-Jabir, A., Iosifidis, C., Agha, M., \& Agha, R. (2020). The socioeconomic implications of the coronavirus pandemic (COVID-19): A review. International Journal of Surgery (London, England), 78, 185. https://doi.org/10.1016/j. ijsu.2020.04.018.

OECD. (2019). Financing SMEs and entrepreneurs 2019: An OECD scoreboard. Paris: OECD Publishing. https://doi. org/10.1787/061fe03d-en.

Paelinck, J., De Caevel, J., \& Degueldre, J. (1965). Analyse quantitative de certaines phénomènes du développement régional polarisé: Essai de simulation statique d'Itéraires de propagation. Bibliothèque de l'Institut de Science Économique, 7, 341-387.

Pasten, E., Schoenle, R., \& Weber, M. (2020). Price rigidities and the granular origins of aggregate fluctuations. Chicago Booth Research Paper, 17-25, 1-48. https://doi.org/10.2139 /ssrn.3022193.

Paul, S., Whittam, G., \& Wyper, J. (2007). The pecking order hypothesis: Does it apply to start-up firms? Journal of Small Business and Enterprise Development, 14(1), 8-21. https://doi.org/10.1108/14626000710727854.

Perobelli, F. S., Faria, W. R., \& de Almeida Vale, V. (2015). The increase in Brazilian household income and its impact on CO2 emissions: Evidence for 2003 and 2009 from inputoutput tables. Energy Economics, 52, 228-239. https://doi. org/10.1016/j.eneco.2015.10.007.

Pyatt, G. (1988). A SAM approach to modeling. Journal of Policy Modeling, 10(3), 327-352. https://doi.org/10.1016/01618938(88)90026-9.

Shane, S. (2009). Why encouraging more people to become entrepreneurs is bad public policy. Small Business Economics, 33(2), 141-149. https://doi.org/10.1007/s11187-009-9215-5.

Smith, R. D., Keogh-Brown, M. R., \& Barnett, T. (2011). Estimating the economic impact of pandemic influenza: An application of the computable general equilibrium model to the UK. Social Science \& Medicine, 73(2), 235-244. https://doi.org/10.1016/j.socscimed.2011.05.025.

Soininen, J., Puumalainen, K., Sjögrén, H., \& Syrjä, P. (2012). The impact of global economic crisis on SMEs Does entrepreneurial orientation matter? Management Research Review, 35(10), 927-944. https://doi.org/10.1108 /01409171211272660.
Song, Y., \& Liu, C. (2007). An input-output approach for measuring real estate sector linkages. Journal of Property Research, 24(1), 71-91. https://doi.org/10.1080 /09599910701297697.

Song, Y., Liu, C., \& Langston, C. (2006). Linkage measures of the construction sector using the hypothetical extraction method. Construction Management and Economics, 24(6), 579-589. https://doi.org/10.1080/01446190500435358.

Stockman, A. C. (1988). Sectoral and national aggregate disturbances to industrial output in seven European countries. Journal of Monetary Economics, 21(2-3), 387-409. https://doi.org/10.1016/0304-3932(88)90037-2.

Strassert, G. (1968). Zur Bestimmung strategischer Sektoren mit Hilfe von input-output-Modellen. Jahrbücher für Nationalökonomie und Statistik, 182(1), 211-215. https://doi.org/10.1515/jbnst-1968-0114.

Temurshoev, U. (2010). Identifying optimal sector groupings with the hypothetical extraction method. Journal of Regional Science, 50(4), 872-890. https://doi.org/10.1111/j.14679787.2010.00678.x.

Thurik, R. (2003). Entrepreneurship and unemployment in the UK. Scottish Journal of Political Economy, 50(3), 264 290. https://doi.org/10.1111/1467-9485.5003001.

Thurlow, J. (2011). Consequences of avian flu for growth and poverty: A CGE analysis for Kenya. African Development Review, 23(3), 276-288. https://doi.org/10.1111/j.14678268.2011.00286.x.

United Nations, Commission of the European Communities, International Monetary Fund, Organization for Economic Co-operation \& Development and World Bank. (2008). System of national accounts 2008. Brussels: World Bank.

Urbano, D., Aparicio, S., \& Audretsch, D. (2019). Twenty-five years of research on institutions, entrepreneurship, and economic growth: What has been learned? Small Business Economics, 53(1), 21-49. https://doi.org/10.1007/s11187018-0038-0.

Verikios, G. (2017). CGE models of infectious diseases with a focus on influenza. In T. Bryant (Ed.), The WSPC reference on natural resources and environmental policy in the era of global change, Volume 3: Computable general equilibrium models (pp. 125-172). Singapore: World Scientific Publishing. https://doi.org/10.1142/9789813208179_0005.

Verikios, G., Sullivan, M., Stojanovski, P., Giesecke, J., \& Woo, G. (2016). Assessing regional risks from pandemic influenza: A scenario analysis. The World Economy, 39(8), 1225-1255. https://doi.org/10.1111/twec.12296.

Wagenvoort, R. (2003). Are finance constraints hindering the growth of SMEs in Europe? European Investment Bank Papers, 8(2), 23-50.

Zhang, D., Hu, M., \& Ji, Q. (2020). Financial markets under the global pandemic of COVID-19. Finance Research Letters, 36, 101528. https://doi.org/10.1016/j.frl.2020.101528.

Publisher's note Springer Nature remains neutral with regard to jurisdictional claims in published maps and institutional affiliations. 